\title{
Micropalaeontology, biostratigraphy, and depositional setting of the mid-Cretaceous Derdere Formation at Derik, Mardin, south-eastern Turkey
}

\author{
Michael D. Simmons ${ }^{1,2}$, Vicent Vicedo ${ }^{3}$, İsmail Ö. Yılmaz ${ }^{4}$, İzzet Hoşgör ${ }^{5}$, Ŏguz Mülayim $^{6}$, and \\ Bilal Sarı ${ }^{7}$ \\ ${ }^{1}$ Halliburton, 97 Jubilee Avenue, Milton Park, Abingdon, OX14 4RW, UK \\ ${ }^{2}$ The Natural History Museum, Cromwell Road, London, SW7 5BD, UK \\ ${ }^{3}$ Departament de Paleontologia, Museu de Ciències Naturals de Barcelona, \\ Passeig Picasso s/n, 08003 Barcelona, Spain \\ ${ }^{4}$ Department of Geological Engineering, Middle East Technical University, 06800, Ankara, Turkey \\ ${ }^{5}$ Çalık Enerji, Oil and Gas Directorate, Söğ̈̈̈tözü, 06510, Ankara, Turkey \\ ${ }^{6} \mathrm{TPAO}$, Turkish Petroleum Corporation, Adıyaman Directorate, 02040, Adiyaman, Turkey \\ ${ }^{7}$ Department of Geological Engineering, Dokuz Eylül Üniversitesi, 35370, İzmir, Turkey
}

Correspondence: Michael D. Simmons (mike.simmons@ halliburton.com)

Received: 20 June 2020 - Revised: 5 September 2020 - Accepted: 11 September 2020 - Published: 5 November 2020

\begin{abstract}
The micropalaeontology of the mid-Cretaceous Derdere Formation (Mardin Group) from outcrops close to the town of Derik in south-eastern Turkey is described here. In thin sections from the carbonates that form the majority of this formation, rich and diverse micropalaeontological assemblages are present. These include larger benthonic foraminifera, planktonic foraminifera, and other microfossils, including calcareous algae. Alveolinid foraminifera are particularly common and include a new species - Simplalveolina mardinensis. In contrast to some previous studies, the majority of the section can be demonstrated to be Cenomanian (notably middle Cenomanian) in age with no confirmation of extension into the Albian or Turonian. Deposition took place on a carbonate ramp within a range of discrete deposition settings ranging from peritidal to outer ramp. A notable feature is the small-scale (a few metres) shallowing-up cycles within the inner-ramp facies that may be allocyclic or autocyclic in origin. Three major deepening events are recognised within the succession, characterised by more open marine microfauna and microfacies. These occur at the base of the formation, within the mid-Cenomanian lower part, and towards the top of the formation. These may correlate with three Cenomanian deepening phases seen in other parts of the Arabian Plate.
\end{abstract}

\section{Introduction}

The mid-Cretaceous Derdere Formation forms part of the Mardin Group (Fig. 1), a thick succession of mostly carbonate Cretaceous rocks known from outcrops and the subsurface in south-eastern Turkey. These were deposited on the northernmost part of the Arabian Plate, which formed part of an extensive carbonate platform on the southern Gondwanan margin of Neotethys.

Although the Derdere Formation is of economic importance, forming both hydrocarbon reservoirs and poten- tial source rocks in the subsurface (e.g. Çelikdemir et al., 1991; Cater and Gillcrist, 1994; Demirel and Guneri, 2000; Demirel et al., 2001; Mülayim et al., 2016), details of its stratigraphy are relatively limited, especially in comparison to coeval sediments elsewhere on the Arabian Plate. Therefore, studies of the micropalaeontology of the Derdere Formation can help determine its biostratigraphy, palaeoenvironments, sequence stratigraphy, and regional correlation. Moreover, it is useful to compare the microfossils (principally benthonic and planktonic foraminifera and calcareous 


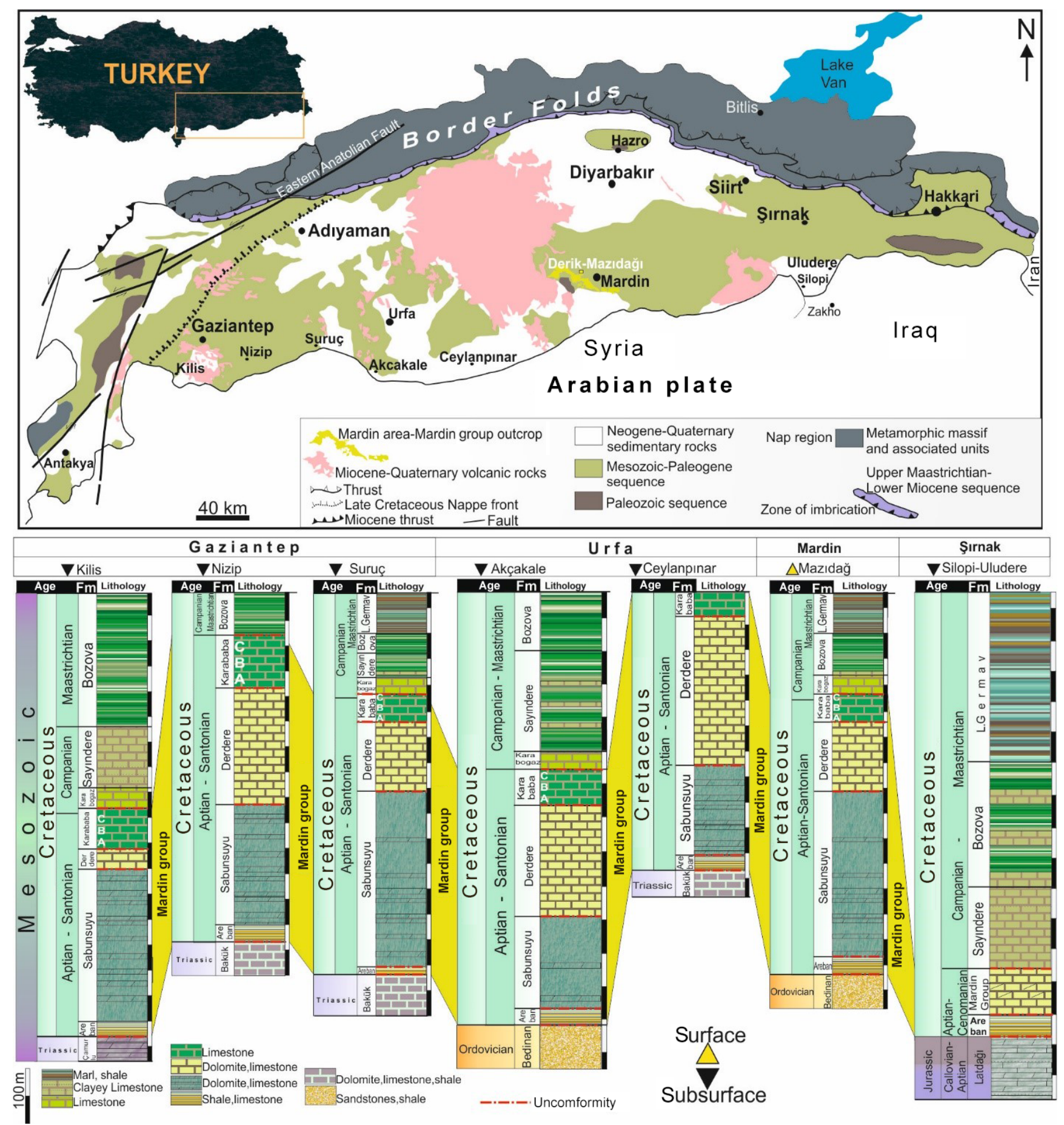

Figure 1. Location of the study area (Derik-Mazıdağı) on a simplified regional geological map and a correlation panel of relevant stratigraphy. 
algae) with coeval fauna elsewhere on the Arabian Plate and in other parts of Neotethys.

This work builds on the pioneering study of Özkan and Altıner (2019), who were the first to describe, in a substantial manner, the micropalaeontology of the Derdere Formation. Our work adds further details to their observations, especially those concerning the larger alveolinid foraminifera, which can now be considered using new taxonomic concepts (e.g. Vicedo and Piuz, 2017), and those concerning age-significant planktonic foraminifera. Our results are considered in a wider context.

\section{Geologic setting}

The south-eastern part of Turkey represents part of the Arabian Plate (or Platform) that is conjoined with the AnatolideTauride Block along a suture zone (Okay and Tüysüz, 1999). During the Mesozoic, these two tectonic units were separated by the southern branch of Neotethys (Şengör and Yilmaz, 1981; Okay et al., 2006).

The Cretaceous succession in south-eastern Turkey on the Arabian Plate is composed of the Mardin (Aptian-Santonian) and Adiyaman (Campanian-Maastrichtian) groups (e.g. Mülayim et al., 2020). The Mardin Group represents deposition on a carbonate platform that developed on the passive, northern edge of the Arabian Plate prior to southerly directed thrusting and related folding (Görür et al., 1991; Cater and Gillcrist, 1994). The Mardin Group is divided into four distinctive formations, from bottom to top: Areban, Sabunsuyu, Derdere, and Karababa. The oldest Cretaceous sediments in the regional succession (Fig. 1) are those of the Aptian Areban Formation, composed of an alternation of sandstones and claystones and lying upon Palaeozoic or Triassic and Jurassic rock units with discordance. The Albian Sabunsuyu Formation is composed of an alternation of dolostones, limestones, and marls and lies conformably on the Areban Formation.

The mid-Cretaceous Derdere Formation forming the focus of this study overlies the Areban and Sabunsuyu Formations with a marked hiatus prior to deposition (Mülayim et al., 2016). It is mainly composed of an alternation of thickbedded limestones, dolomitic limestones, and dolostones. The Derdere Formation is normally separated by a slight hiatus from the overlying Turonian-lower Campanian Karababa Formation (Mülayim et al., 2019a). The Karababa Formation is composed of an alternation of organic-rich pelagic limestones, cherty limestones, and bioclastic limestones, comprising members A, B, and C, respectively. The lower-middle Campanian Karaboğaz Formation unconformably lies on the Karababa Formation. The Karaboğaz Formation is composed of an alternation of organic-rich pelagic limestones and cherty limestones. The Lower Germav Formation of Campanian-Maastrichtian age lies above the Karaboğaz Formation with an unconformity. It is composed of alternation of shales and marls and includes common pelagic fossils.
Cenozoic lithostratigraphic units overlie the Cretaceous units conformably in the study area and are composed mainly of alternations of carbonates and siliclastics.

\section{Previous work}

A number of publications have reviewed the stratigraphy of the Derdere Formation in south-eastern Turkey, but only the paper by Özkan and Altıner (2019) provides detailed micropalaeontological analysis. Previous publications present a slightly confusing set of interpretations in terms of age, depositional environment, and sequence stratigraphy. All publications agree that the Derdere Formation is at least in part Cenomanian in age, but some extend the age of the formation into the Turonian (e.g. Çelikdemir et al., 1991; Görür et al., 1991; Cater and Gillcrist, 1994; Cros et al., 1999; Demirel and Guneri, 2000; Robertson et al., 2016; Mülayim et al., 2016; Özkan and Altıner, 2019) or Albian (Özkan and Altıner, 2019). Others differ on which part of the Cenomanian the formation should be assigned to (compare Mülayim et al., 2018, 2020). Whilst most papers agree that the Derdere Formation represents deposition on a shallow marine carbonate platform, deeper water intervals are recognised, sometimes at the base of the formation and sometimes towards the top. These differences may in part be explained by widespread occurrence of the Derdere Formation in south-eastern Turkey, at outcrop and in the subsurface, and hence differences in palaeogeographic setting. The MardinDerik region is clearly proximal in depositional setting compared to the outcrops and oilfields in the foothills south of the Bitlis Fault ("Miocene thrust" in Fig. 1), around $100 \mathrm{~km}$ to the north (e.g. Çelikdemir et al., 1991; Cater and Gillcrist, 1994; Demirel and Guneri, 2000). Differential erosion at the contact with the overlying Karababa Formation (Mülayim et al., 2016) may be a factor leading to differing age interpretations, and there may be issues in picking the boundary with the underlying Sabunsuyu Formation.

Many previous studies of the Derdere Formation have concentrated on outcrops or wells over $100 \mathrm{~km}$ to the north and west of the Derik section that forms the focus of this study. At these locations the Derdere Formation has a rather different character than at Derik (e.g. Görür et al., 1991; Mülayim et al., 2016), notably lacking alveolinid-rich packstones and grainstones. Mülayim et al. (2020) studied the Derdere Formation at Sabunsuyu in Kilis province. There, unlike at Derik, the Derdere Formation $(68.9 \mathrm{~m}$ thick) is rich in rudist bivalves. It contains deeper water facies (i.e. planktonic foraminifera and calcispheres) towards its base and overall is thought to be middle-late Cenomanian in age, based on the rudist fauna present and the presence of the planktonic foraminifera Asterohedbergella asterospinosa (Hamaoui). Much of the succession at Sabunsuyu appears to be of a more distal depositional setting than the Derik section reported on herein. 
Derdere Formation material from wells in the Adiyaman region, over $100 \mathrm{~km}$ to the north-west of Derik, have yielded roveacrinid fragments (Mülayim et al., 2018). Here, the Derdere Formation is thought to be early-middle Cenomanian, in part based on the roveacrinids present. The lower part of the formation is organic carbon-rich (Demirel and Guneri, 2000; Demirel et al., 2001), deposited in relatively deep water, and passes up into a shallowing-upwards sequence of lagoonal and tidal-flat carbonates (Çelikdemir et al., 1991). Mülayim et al. (2019b) considered the Derdere Formation at Türkoğlu (also some distance to the north-west of Derik) to be as old as early Cenomanian based on the presence (not illustrated) of Ovalveolina maccagnoae De Castro.

An important paper is that of Mülayim et al. (2019a), who studied the Derdere and overlying Karababa formations at outcrop at İnişdere, in the Adıyaman region. Here, the authors were able to demonstrate that, at this locality at least, the base of the Karababa Formation corresponds to the Cenomanian-Turonian Boundary Event, where anoxia and sea level rise contribute to the demise of the Derdere carbonate platform. Carbon isotope stratigraphy at Türkoglu (Mülayim et al., 2019b) supports this notion. In the Karababa Formation, constraint is provided by planktonic foraminifera, calcareous nannofossils, and carbon isotope data and demonstrates that despite a number of suggestions in the literature that the Derdere Formation extends into the Turonian (see paragraphs above), this is in fact unlikely. By virtue of the age of the overlying Karababa Formation, the Derdere Formation is essentially a Cenomanian rock unit.

\section{Materials and methods}

The study area lies in the Mardin region of south-eastern Turkey, approximately $4 \mathrm{~km}$ north-east of the village of Derik, on the road towards Mazıdağ (Fig. 2). Two stratigraphic sections, one in the lower part of the Derdere Formation (Fig. 3) and the other in the upper part of the Derdere Formation (Fig. 4), form one composite stratigraphic section, $63.94 \mathrm{~m}$ thick, which has been measured and had its sedimentology described. Poor exposure prevents the contacts with the underlying Sabunsuyu and overlying Karababa Formations from being seen, but from field relations the section represents the majority of the Derdere Formation present in this area, especially if repetition of the section by minor faulting is discounted.

A total of 70 samples for thin-section study have been collected bed by bed, with thick beds sampled at their base, middle, and top. Oriented samples were also collected to identify any current orientation in the rock fabric.

Cyclic alternations of facies have been determined in the field by checking sedimentary structures, fossils, and lithology content. This was crossed-checked by subsequent petrographic examination. Benthonic and planktonic foraminifera, calcareous algae, and other microfossils were identified from petrographic examination, and provide biostratigraphic calibration and assist in palaeoenvironmental determination and the identification of any stratigraphic trends in palaeobathymetry as determined from microfossil content.

\section{The Derdere Formation at Derik}

At outcrop scale, the lower Derdere Formation is mostly composed of bioturbated thick-bedded limestones alternating with medium-bedded bioclastic limestones. The upper Derdere Formation consists of an alternation of dolostones and thick-bedded limestones. Cyclic alternations of facies are typical and visible at outcrop and from subsequent petrography. Cater and Gillcrist (1994) recognised five major cycles (termed members) in the Derdere Formation in the DerikMazıdağı region, and noted the presence of karst surfaces in the succession, an observation we concur with.

The lowest $7 \mathrm{~m}$ of the studied section (Fig. 3) consists of bioturbated, medium-bedded dolomitised limestones (mudstones-wackestones) with a sparse fauna of planktonic foraminifera and echinoderm debris (Fig. 5.1). This passes up into $\sim 2 \mathrm{~m}$ of wackestones and packstones with calcareous algae, discorbids and alveolinid foraminifera (Fig. 5.25.3), and a capping hardground.

Above this is $\sim 15 \mathrm{~m}$ of cycles (Fig. 3) that typically begin with grainstones (sometimes cross-bedded) containing alveolinids, calcareous algae, echinoderm, and rudist bivalve fragments (Fig. 5.4, 5.6), passing up into burrowed wackestones-packstones (Fig. 5.5) with echinoderm debris and a variety of benthonic foraminifera (e.g. Nautiloculina, Cuneolina, Ammobaculites/Lituola and occasional alveolinids and indeterminate orbitolinids). Cycles are typically on the scale of a few metres and may be capped by hardgrounds, microkarst or possibly rootlet horizons (Fig. 5.7).

Around $23 \mathrm{~m}$ from the base of the section, facies have a different character than that immediately below and consist mostly of bioclastic-peloidal wackestones with some planktonic foraminifera (Fig. 6.1, 6.2). Occasional interbeds of relatively coarse bioclastic packstone are present (Fig. 6.3).

Above $29 \mathrm{~m}$ from the base of the section the character of the section changes rapidly, passing into fenestral mudstones (Fig. 6.4) with micro-coprolites, birds-eye vugs and mudcracks, or dolosparites (Fig. 3).

The upper Derdere Formation (Fig. 4) has a comparatively more monotonous character. Dolomitised mudstones and wackestones alternate with non-dolomitised beds with variable abundance of bioclasts, mostly planktonic foraminifera and calcispheres (Fig. 6.5-6.7).

Within the upper Derdere Formation are monogenic bivalve accumulations (Aphrodina dutrugei (Cocquand)) in sharp or erosional contact with underlying sediments. The shells are oriented towards 112,132 , and $143^{\circ}$ and are imbedded in a micritic matrix. Most shells are replaced by sparry calcite and the shell moulds are infilled by a partially dolomi- 


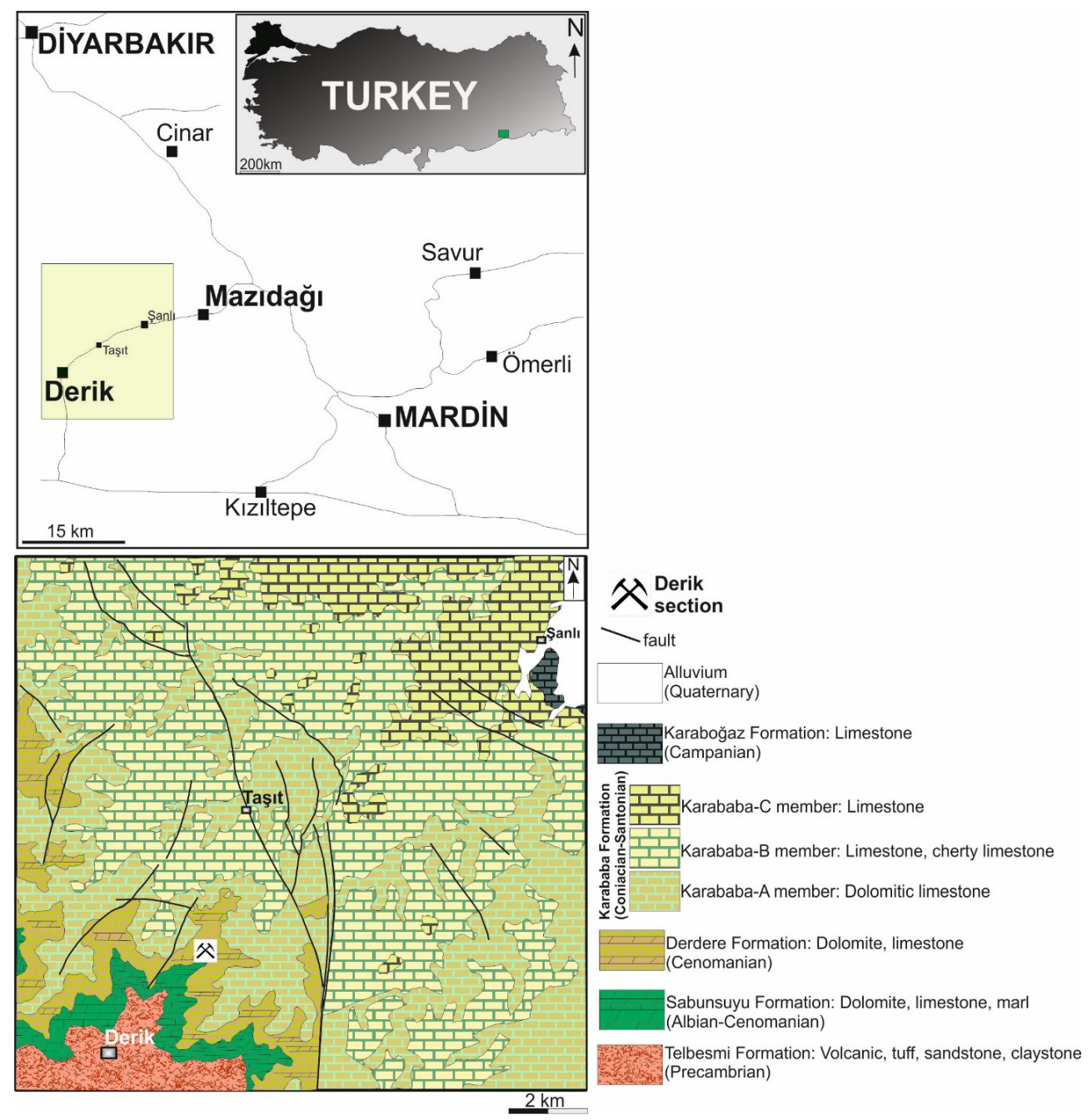

Figure 2. Location of the studied section. Regional geological map (following Beer, 1966; MTA, 2011).

tised peloidal grainstone facies, completely different from the surrounding matrix. Hoşgör and Yılmaz (2019) have described this bivalve accumulation and commented on its palaeogeographic importance.

Our description of the Derdere Formation in the Derik region can be contrasted with that of Özkan and Altıner (2019), who considered the formation to be over $300 \mathrm{~m}$ thick and heavily dolomitised. Whilst we recognise some dolomite beds, we recognise many fewer than Özkan and Altıner (2019). Moreover, their measured thickness is incompatible with our observations and that of most previous studies. Our section is just over $60 \mathrm{~m}$ thick, and whilst incomplete would be unlikely to exceed $100 \mathrm{~m}$, a thickness that matches many previous observations (e.g. Çelikdemir et al., 1991; Cater and Gillcrist, 1994). We can only assume that Özkan and Altıner (2019) may have failed to account for fault repetition in the succession, as their overall pattern of deposition interestingly matches our own. Like us, they recognise an open marine succession at the base of the formation, passing up into shallow marine lagoonal facies and returning to more open marine facies at the top of the formation. Unlike us, they attribute the oldest part of the formation to the Albian and the youngest to the Turonian.

\section{Microfossil assemblages}

The Derdere Formation in the studied section often contains rich assemblages of microfossils as seen in thin-section. These include benthonic foraminifera (notably alveolinids), planktonic foraminifera, and calcareous algae. Other microfossils such as calcispheres are sporadically present. The richness of the microfossil assemblage was first described by Özkan and Altıner (2019), but we have found additional important microfossils they did not recognise. Furthermore, the alveolinids present can be described using recent taxonomic concepts (e.g. Vicedo and Piuz, 2017). The distribution of microfossils recognised in this study is shown in Figs. 3 and 4, and key taxa are illustrated in Figs. 7-12. 


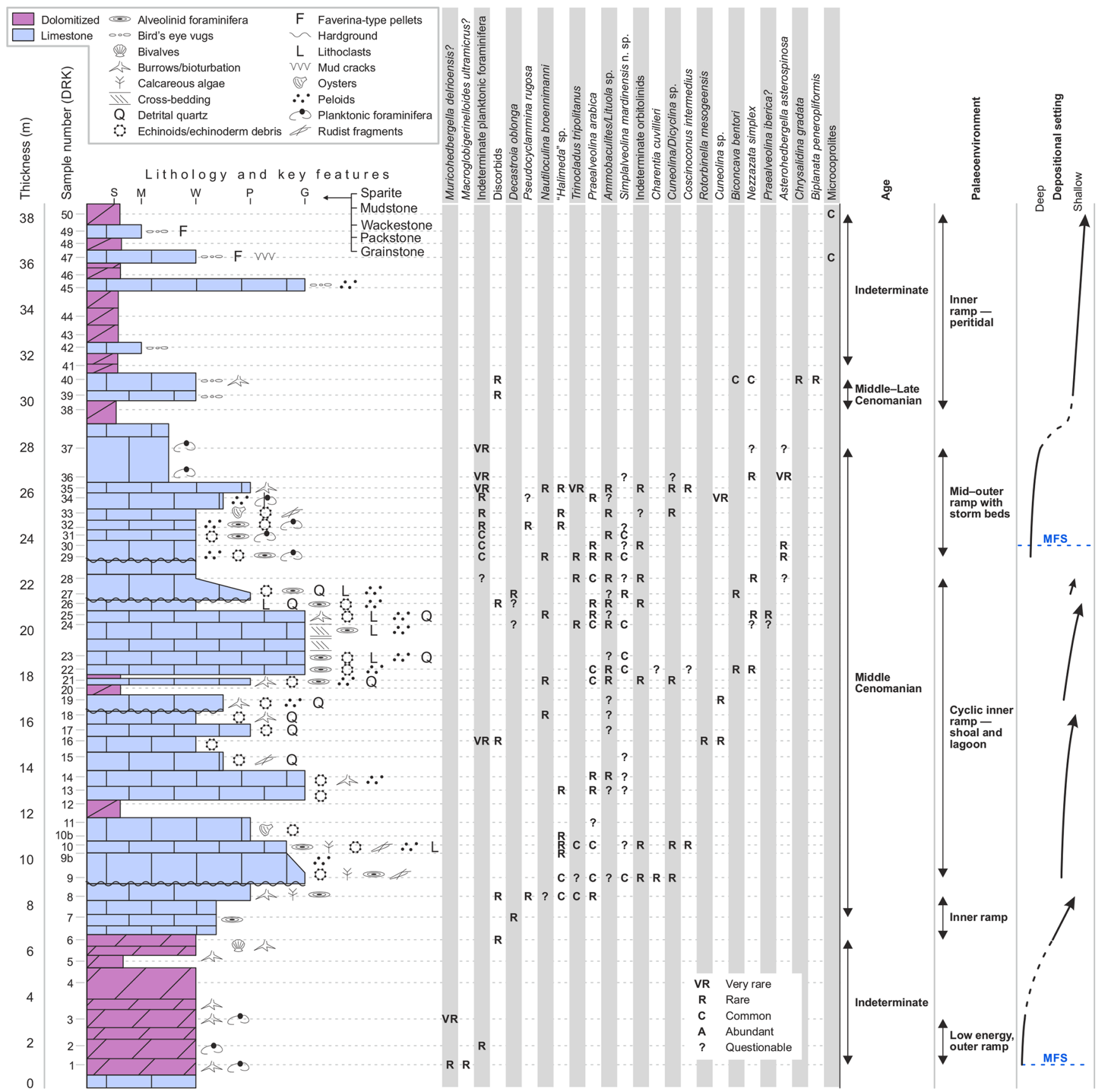

Figure 3. Lower Derdere Formation at Derik with sedimentological and petrographic information, micropalaeontology, age and palaeoenvironmental interpretation, and identification of deposition trends. MFS stands for possible maximum flooding surface.

\subsection{Benthonic foraminifera}

Alveolinids occur throughout much of the Derdere Formation, although their preservation is variable. Often found in grainstones, they can be abraded such that key features for their identification can be missing. Özkan and Altıner (2019) recognised a number of alveolinids within the Derdere Formation. These included Praealveolina spp.; Sellialveolina quintanensis Vicedo, Calonge, and Caus; Sellialveolina vial- lii Colalongo; Praealveolina tenuis Reichel; Praealveolina cretacea (d'Archiac); Praealveolina iberica Reichel; and Ovalveolina ovum (d'Orbigny). We have found a rather different fauna, dominated by Simplalveolina (Simplalveolina mardinensis $\mathrm{n}$. sp.) and forms attributable to Decastroia oblonga Vicedo and Piuz and Praealveolina cf. arabica Vicedo and Piuz. We have employed a relatively new taxonomy of mid-Cretaceous alveolinids (e.g. Vicedo and Serra-Kiel, 2011; Vicedo and Piuz, 2017) that recognises new, prob- 


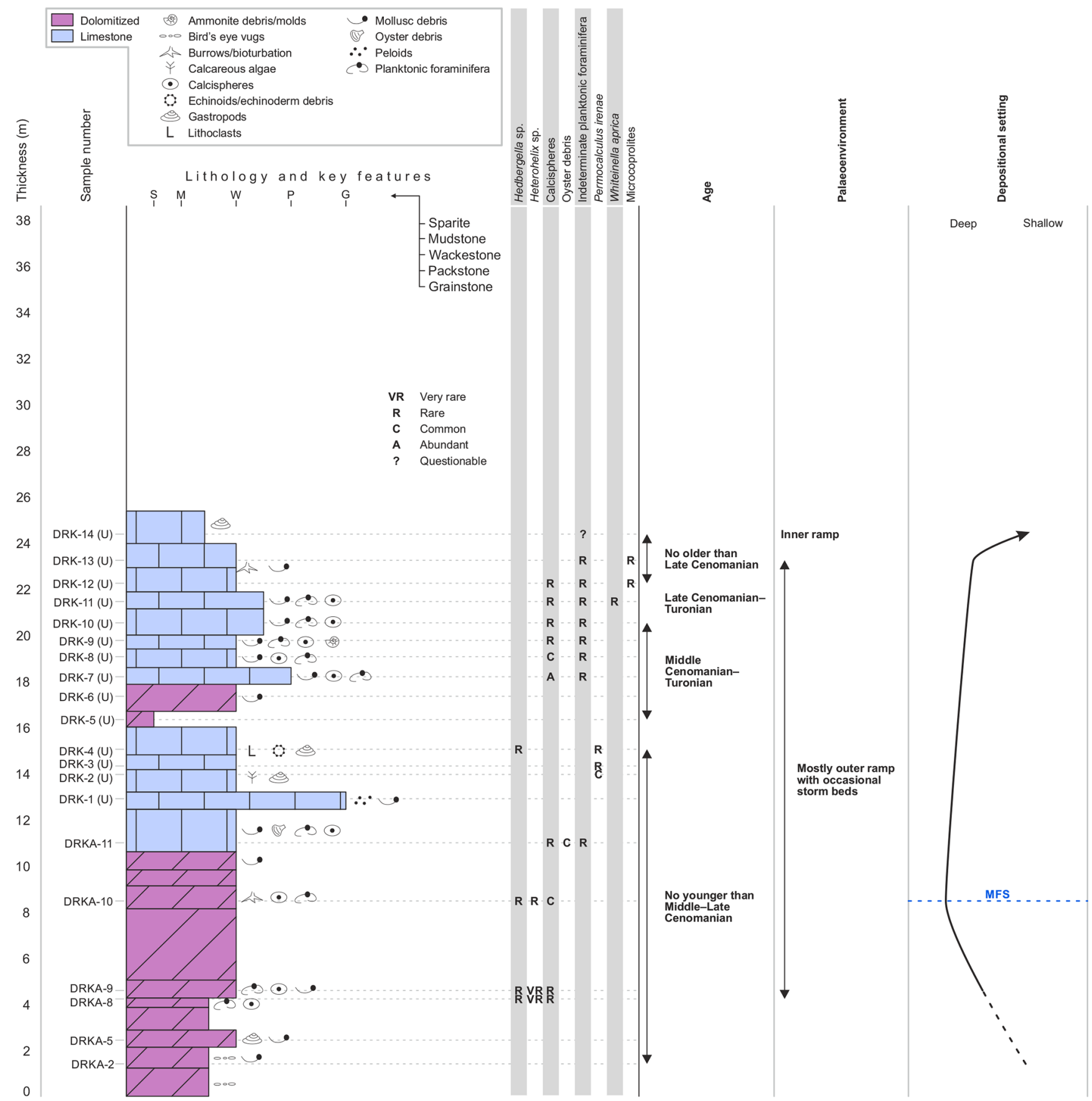

Figure 4. Upper Derdere Formation at Derik with sedimentological and petrographic information, micropalaeontology, age and palaeoenvironmental interpretation, and identification of deposition trends. MFS stands for possible maximum flooding surface.

ably endemic, genera and species of Arabian alveolinids, potentially confusable with established species such as $P$. cretacea and $P$. tenuis. Even so, the restrictions of random thin sections and poor preservation means that many specimens cannot be identified more precisely than "Praealveolina/Decastroia".

Common within the studied material is a new species of alveolinid, Simplalveolina mardinensis n. sp. A formal de- scription is provided in Appendix A and the species is illustrated in Figs. 7 and 8.1-8.2. Similar to Simplalveolina simplex (Reichel), it can be distinguished by its smaller proloculus, smaller axial diameter, and fewer whorls. Some of the alveolinids described from the Derdere Formation by Özkan and Altıner (2019) as P. iberica, may be S. mardinensis, although the illustrations are uncertain. S. simplex was recorded from the Derdere Formation by Görür et al. (1991) 

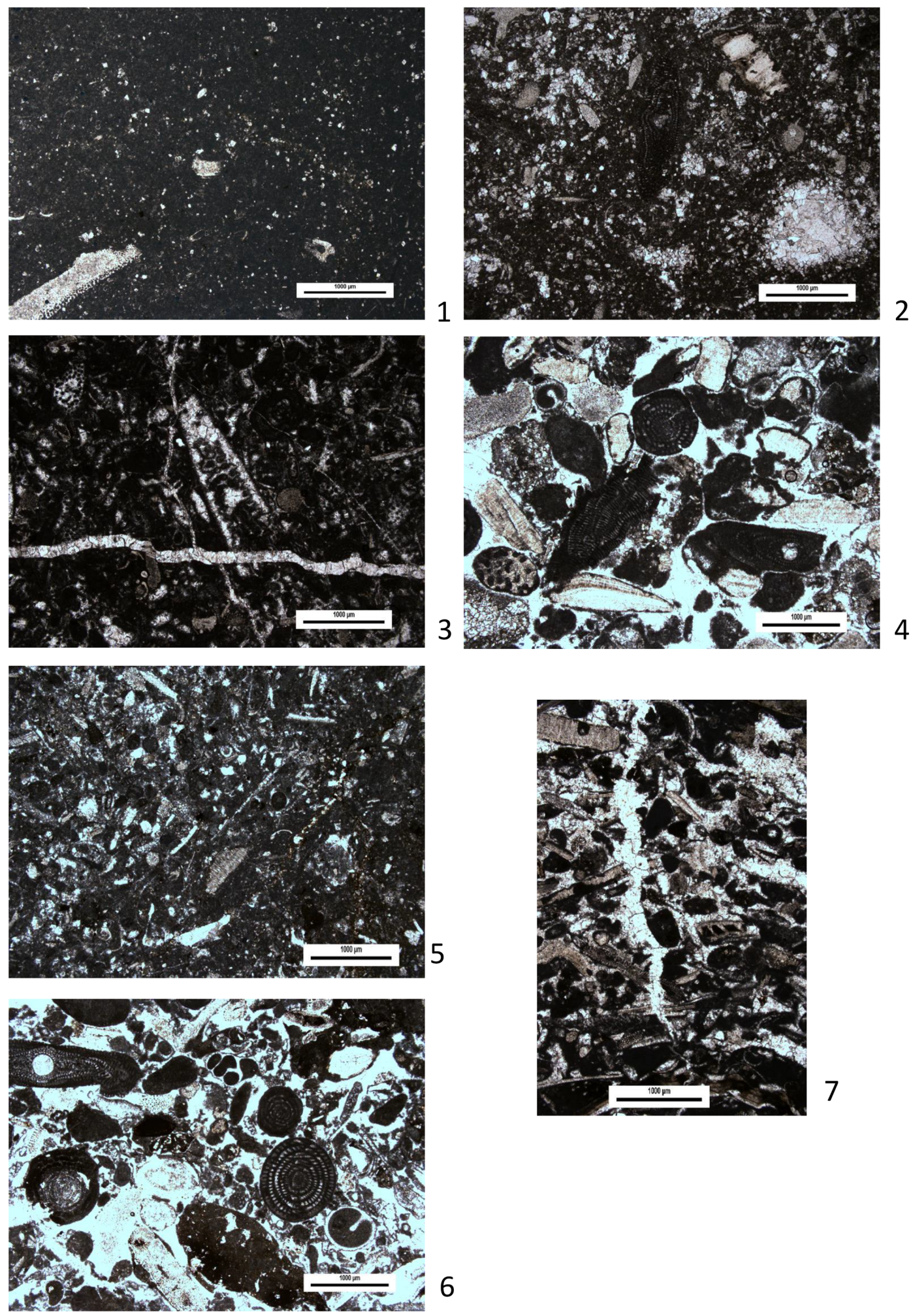

Figure 5. Derdere Formation microfacies: (1) DRK1 - bioclastic mudstone/wackestone with echinoderm debris and planktonic foraminifera; (2) DRK7 - bioclastic wackestone with mollusc and echinoderm debris and rare alveolinid foraminifera; (3) DRK8 - bioclastic wackestone with dasycladalean and udotacean algae and echionderm debris; (4) DRK9 - Bioclastic grainstone with alveolinid foraminifera, mollusc, and echinoderm debris; (5) DRK16 - bioclastic wackestone with echinoderm and mollusc debris and rare discorbid foraminifera; (6) DRK22 bioclastic-peloidal-lithoclast grainstone with common mollusc and echinoderm debris and alveolinid foraminifera; (7) DRK19 - peloidalbioclastic packstone with mollusc debris and possible rootlet and microkarst. The scale bar is $1000 \mu \mathrm{m}$. 

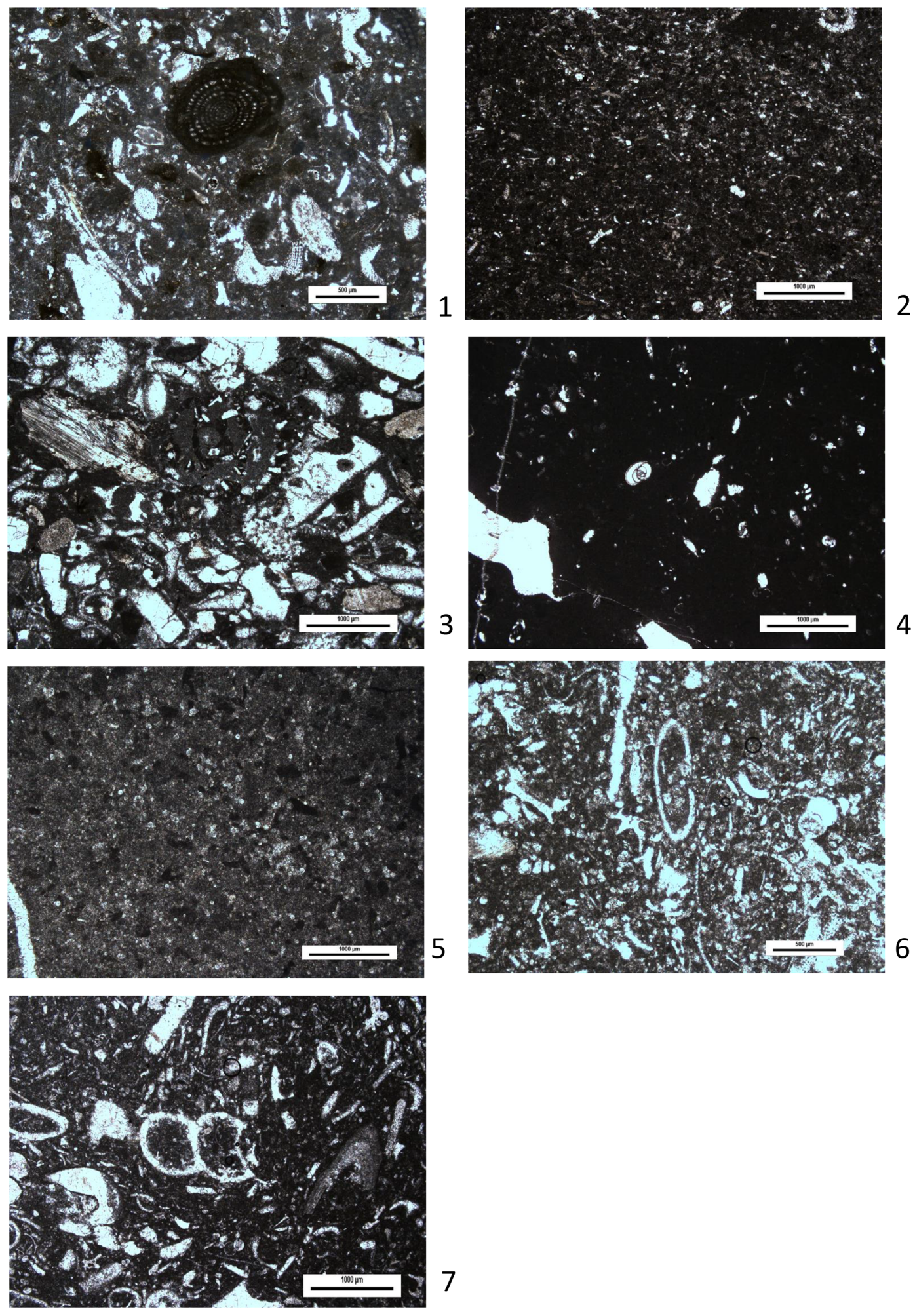

Figure 6. Derdere Formation microfacies: (1) DRK30 - bioclastic wackestone with mollusc and echinoderm debris, planktonic foraminifera, and alveolinid foraminifera; (2) DRK34 - fine peloidal wackestone - packstone with rare planktonic foraminifera; (3) DRK35 - coarse bioclastic packstone, mostly mollusc (?rudist) debris, and lituolid foraminifera; (4) DRK39 - fenestral mudstone - wackestone with miliolid foraminifera and ostracods; (5) DRKA8 - bioclastic mudstone - wackestone with calcispheres and planktonic foraminifera; (6) DRK7(U) - bioclastic wackestone - packstone with calcispheres and mollusc debris; (7) DRK10(U) - bioclastic wackestone with mollusc debris, planktonic foraminifera, and calcispheres. The scale bar is $1000 \mu \mathrm{m}$, except for in (1) and (6), where it is $500 \mu \mathrm{m}$. 
without illustration and could refer to $S$. mardinensis n. sp. Sometimes recorded as Praealveolina simplex, S. simplex has been reported from the Arabian Plate (e.g. Sampo, 1969; Ghanem et al., 2012; Afghah and Fadaei, 2015). In many cases, illustrations are inadequate to check that they are not $S$. mardinensis. The specimen illustrated by Parnian et al. (2019) is not a Simplalveolina at all.

The genus Decastroia (type species Decastroia razini) was introduced by Vicedo and Serra-Kiel (2011), who recognised that Arabian Plate Cenomanian alveolinid fauna have distinct morphological aspects. The distinctive feature of $D e$ castroia is the presence of two superposed rows of apertures visible on the apertural face from pole to pole, with those in the upper row having a larger diameter than those in the lower row. Furthermore, two rows of chamberlets are present within which whorl of the test: large upper cortical chamberlets and smaller lower medullar chamberlets. These features serve to distinguish the genus from the superficially similar Cisalveolina, Ovalveolina and Praealveolina.

D. oblonga was introduced by Vicedo and Piuz (2017) based on material from the Oman Mountains, for highly dimorphic, axially elongated forms of Decastroia. Such forms from the Middle East may have previously been described as P. tenuis (e.g. Smith et al., 1990) or P. cretacea. This species is now confirmed as occurring in a different part of the Arabian Plate through its sporadic occurrence within the lower Derdere Formation (Fig. 8.3-8.7). In Oman, the occurrence of D. oblonga seems to be limited to the middle Cenomanian, although this range could be extended if previous records of P. tenuis or P. cretacea are shown to be this species. Specimens described as $P$. tenuis from the Derdere Formation by Özkan and Altıner (2019) may be this species, although their illustrations limit comparison.

P. arabica was introduced by Vicedo and Piuz (2017) for praealveolinids from the Cenomanian of Oman with a smaller test size, smaller proloculus, and fewer whorls in adult megalospheric specimens than the well-known species $P$. cretacea and P. tenuis (see Calonge et al., 2002, for descriptions of these species). A number of specimens in the Derdere Formation resemble $P$. arabica, especially in respect to proloculus size $(230-270 \mu \mathrm{m})$, but poor overall preservation requires them to be identified as Praealveolina cf. arabica (Fig. 8.8). P. cretacea has been widely reported from the Arabian Plate. It is quite possible that many of the records of this species are in fact of $P$. arabica, including those from the Derdere Formation documented by Özkan and Altıner (2019). At its type locality, P. arabica is of middle to early late Cenomanian age.

In addition to alveolinids, a number of other larger benthonic foraminifera are present in the lower Derdere Formation. These include large complex lituolids such as Pseudocyclammina rugosa (d'Orbigny) (Fig. 9.1). This species was first described from the Cenomanian of France and has occasionally been recorded from Cenomanian strata in the Middle East (e.g. Simmons and Hart, 1987; Mouty et al., 2003;
Omidvar et al., 2014; Assadi et al., 2016). Özkan and Altıner (2019) did not record it in their study of the Derdere Formation.

In addition to $P$. rugosa, more simple large lituolids are quite common throughout the lower Derdere Formation. These are planispiral (sometimes uncoiling in the final chambers), coarsely agglutinating forms. Sometimes the presence of silt grains in the wall can suggest an alveolar wall structure, but this is misleading - the walls are not alveolar as are they in Pseudocyclammina or Buccicrenata. Those forms with a single aperture can be referred to Ammobaculites; those with multiple apertures can be referred to Lituola. However, in random and sometimes poorly preserved thin sections the nature of the aperture can be difficult to determine. Such forms are thus referred to Ammobaculites/Lituola sp. (Fig. 9.2). The species-level taxonomy of this group is highly uncertain.

Fragments of orbitolinid foraminifera (Fig. 9.3-9.4) occur sporadically throughout the lower section of the Derdere Formation. Random orientation and poor preservation prevent identification to even generic level, but some seem close to Orbitolina sensu lato, whilst others are closer to "Dictyoconus" sensu lato (note that true Dictyoconus is a Maastrichtian-Palaeogene genus; Schlagintweit et al., 2016). The presence of Orbitolina is important because it indicates an age no younger than middle Cenomanian (Schroeder and Neumann, 1985; Velić, 2007). Orbitolina was not recorded from the Derdere Formation by Özkan and Altıner (2019), but they did record Dictyoconus from the lower Derdere Formation, their illustration of which is similar to some of the taxa recorded here.

Charentia cuvillieri Neumann (Fig. 9.5-9.6) occurs sporadically in the lower section of the Derdere Formation. It was not recorded by Özkan and Altıner (2019) in their study of the Derdere Formation but was recorded by them from the base of the underlying Sabunsuyu Formation. Originally described from the Cenomanian of the Île de Madame, south-western France, this species was reviewed by ArnaudVanneau (1985), who noted that it has a long stratigraphic range (see also Schlagintweit, 2014) but occurs no younger than middle Cenomanian. It has widely been reported from across the Arabian Plate in both Early and mid-Cretaceous strata (e.g. Ghanem et al., 2012; early Cenomanian, Palymyrides, Syria).

Forms resembling Cuneolina sensu lato occur sporadically with the lower Derdere section (Fig. 9.7-9.10). Some are too small and insufficiently fan-shaped to be the well-known mid-Cretaceous species, Cuneolina pavonia parvaHenson, and have closer similarities to Early Cretaceous cuneolinids such as Cuneolina laurentii Sartoni and Crescenti, Cuneolina camposaurii Sartoni and Crescenti, and Vercorsella arenata Arnaud-Vanneau and Vercorsella scarsellai (De Castro). V. scarsellai was reported from the lower part of the Derdere Formation by Özkan and Altıner (2019). Others are more 


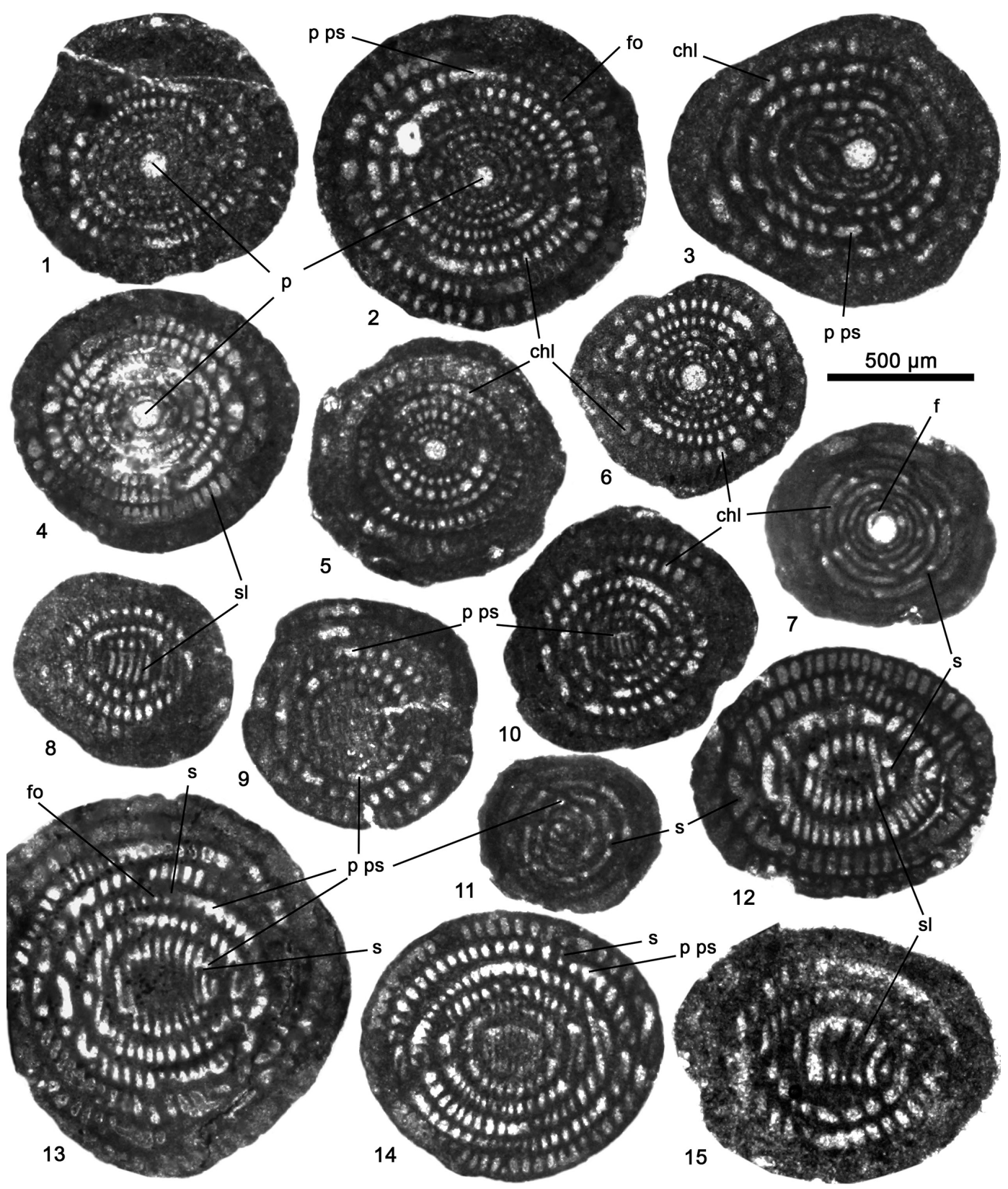

Figure 7. Simplalveolina mardinensis n. sp. from the middle Cenomanian, Derdere Formation at Derik, Mardin, south-eastern Turkey. Transmitted light photographs of thin sections of cemented carbonate rocks. Specimens cut off from surrounding matrix: (1, 2, 4) Sample DRK29, $(\mathbf{3}, \mathbf{5 , 9}, \mathbf{1 5})$ Sample DRK9, (6, 8, 10) Sample DRK23, (7, 11, 14) Sample DRK22, and $(\mathbf{1 2}, \mathbf{1 3})$ Sample DRK24. Plate $(\mathbf{1})$ is the holotype, and Plates (2)-(15) are paratypes. Architectural element abbreviations used in this figure and Fig. 8 are as follows: c chl, cortical chamberlet; chl, chamberlet; f, flexostyle; fo, foramina; $\mathrm{m}$ chl, medullar chamberlet; p, proloculus; p ps, preseptal passage; s, septum; sl, septulum; sp chl, supplementary chamberlet. See the glossary of Hottinger (2006) and Vicedo (2009) for the definition of terms.

clearly fan-shaped, although they are fragmentary and are thus referred to as "Cuneolina/Dicyclina".

Valvulinids and chrysalidinids are rare in the Derdere Formation, but Chrysalidina gradata d'Orbigny is present towards the top of the lower Derdere Formation (Fig. 10.1). This species is distinctively triserial with an internal structure formed of pillars and buttresses (Banner et al., 1991).
Originally described from Cenomanian strata in France, this species has a well-defined middle-late Cenomanian stratigraphic range within Tethys (De Castro, 1985; Velić, 2007). On the Arabian Plate the species has numerous records, including, for example, Banner et al. (1991) from the Natih Formation of Oman (see also Simmons and Hart, 1987; Smith et al., 1990; Piuz et al., 2014) and from the Sarvak 


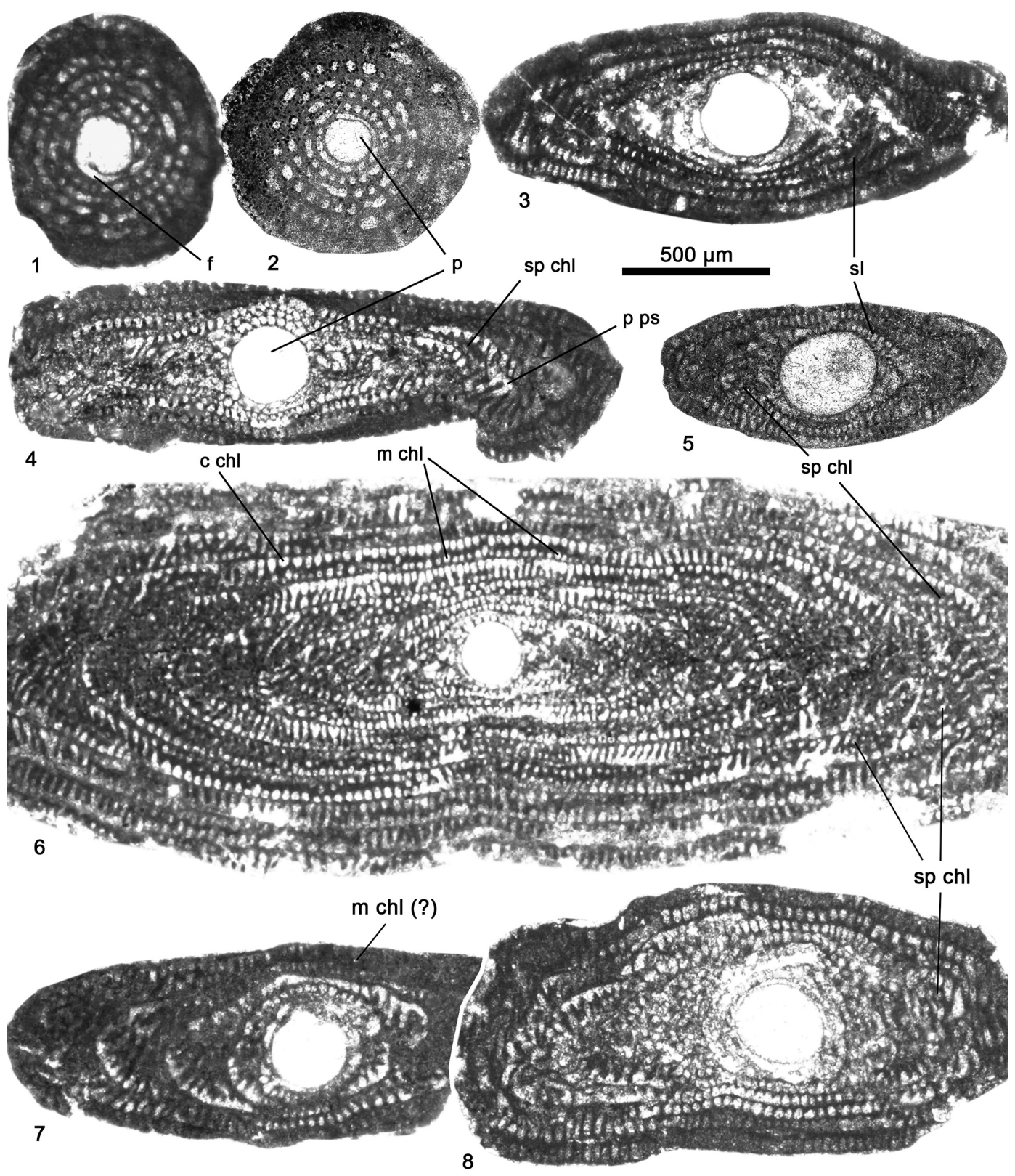

Figure 8. (1, 2) Simplalveolina mardinensis? n. sp. (gamonts?); (3-7) Decastroia oblonga Vicedo and Piuz (3-5 and 7, juvenile specimens); and 8, Praealveolina cf. arabica Vicedo and Piuz from the middle Cenomanian, Derdere Formation at Derik, Mardin, south-eastern Turkey. Transmitted light photographs of thin sections of cemented carbonate rocks. Specimens are cut off from the surrounding matrix: (1, 3, 4) Sample DRK22, (2) Sample DRK25, (5) Sample DRK26, (6) Sample DRK27, and (7, 8) Sample DRK9.

Formation of Iran (see also Cherchi and Schroeder, 1990; Rahimpour-Bonab et al., 2012; Afghah and Fadaei, 2015; Afghah et al., 2014; Assadi et al., 2016); Al-Dulaimy and Al-Sheikhly (2013) from the Mishrif Formation of southern Iraq; Sartorio and Venturini (1988) from Yemen; and Schulze et al. (2004) from Jordan. The majority of these records are in keeping with a middle-late Cenomanian age calibration, although some records are possibly early Cenomanian. These may refer to transitional forms between Praechrysalidina infracretacea Luperto-Sinni and C. gradata (see Banner et al., 1991) or where the age calibration needs further investigation. This species was not recorded by Özkan and Altıner (2019) in their study of the Derdere Formation. Solak et al. (2019) have recorded it from the Cenomanian of the Turkish Taurides.

Trocholinids occur in the lower Derdere Formation, some of which conform to Coscinoconus intermedius (Henson) (Fig. 10.2-10.4). This species was originally described as 

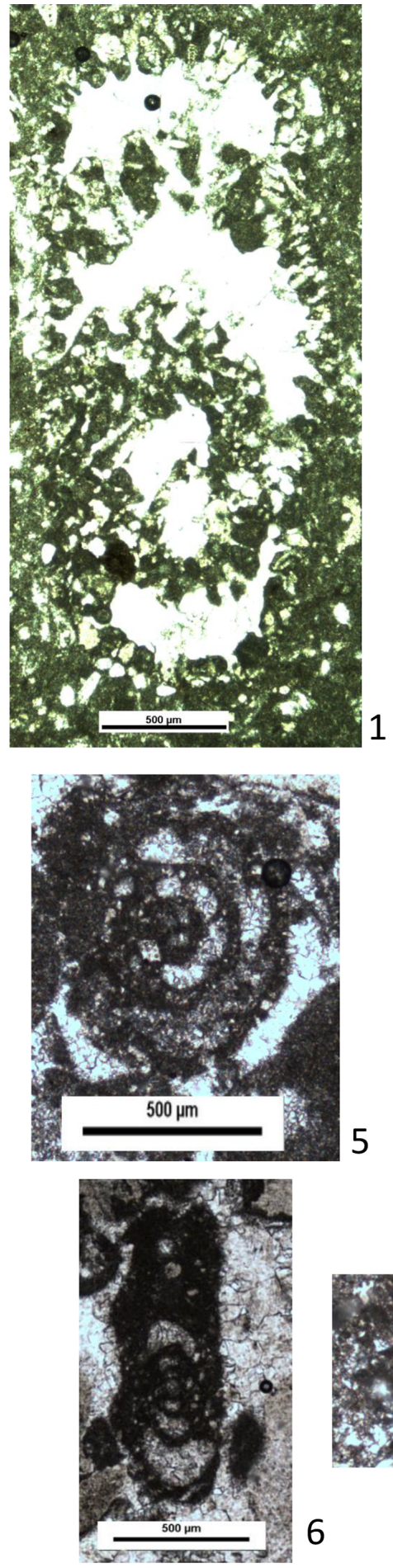
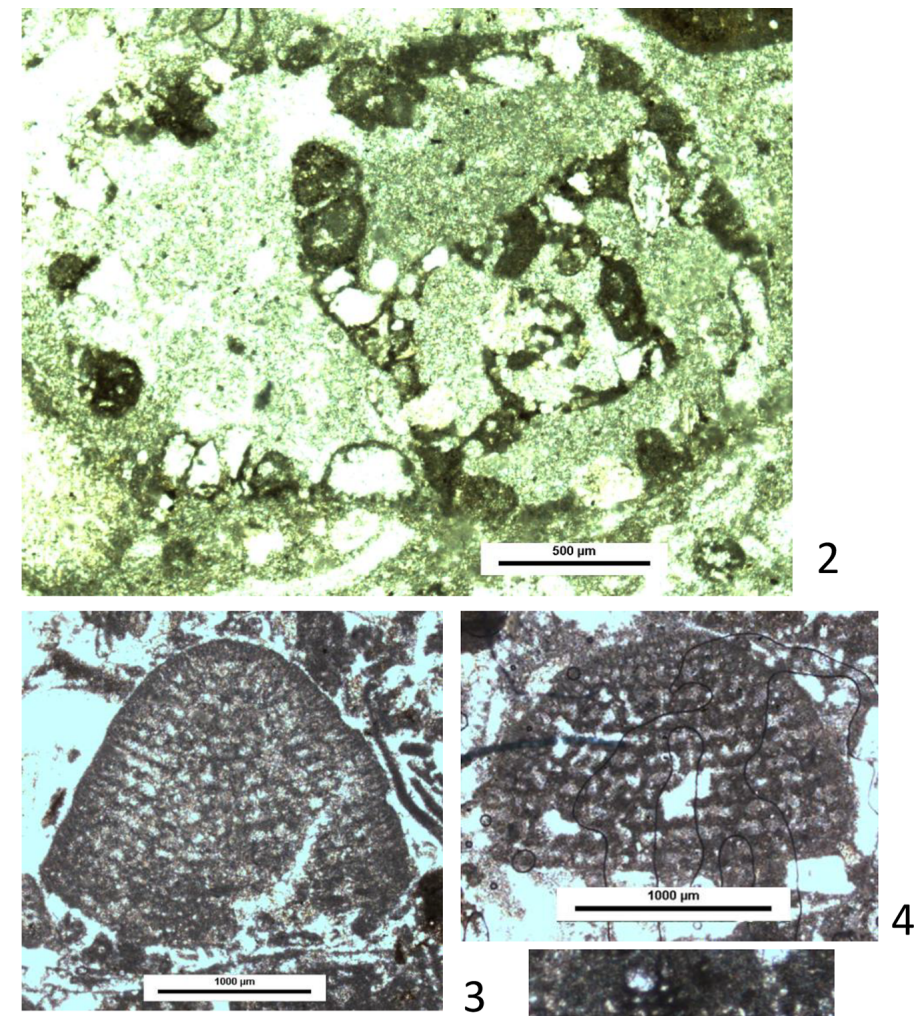

3
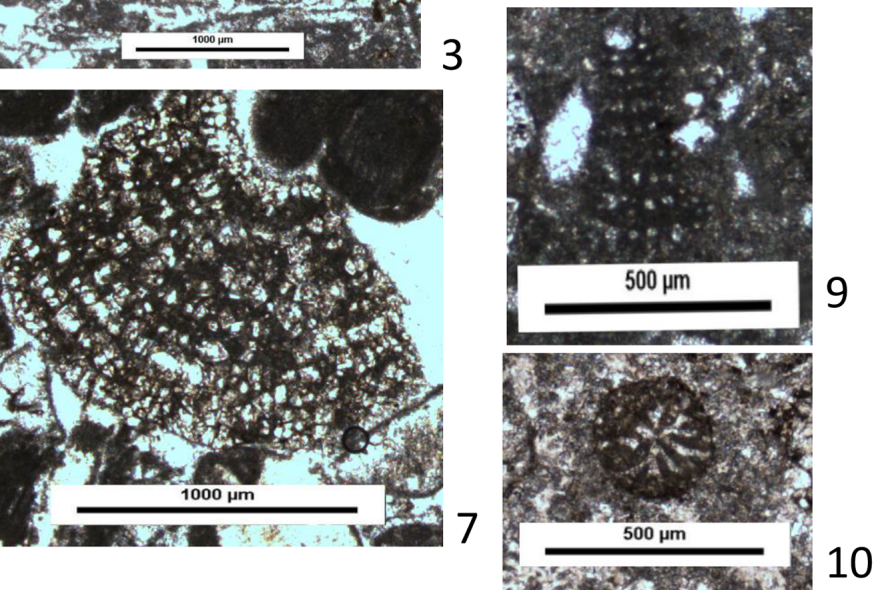

10

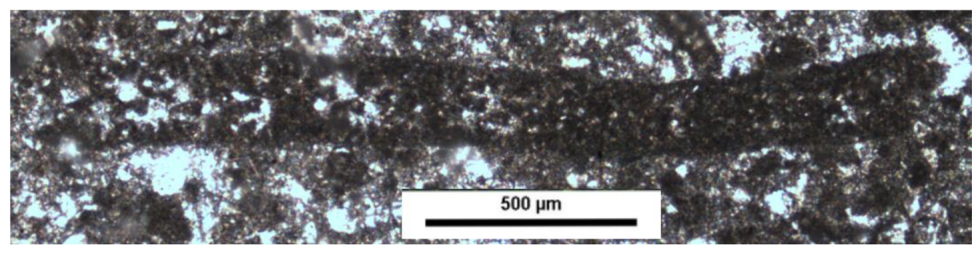

8

Figure 9. Thin-section photographs of benthonic foraminifera from the Derdere Formation at Derik: (1) Pseudocyclammina rugosa (d'Orbigny), sample DRK32; (2) Ammobaculites/Lituola sp., sample DRK35; (3, 4) indeterminate orbitolinid, samples DRK10 and DRK35; (5, 6) Charentia cuvillieri Neumann, sample DRK9; (7, 8) Cuneolina/Dicyclina sp., samples DRK9 and DRK34; (9, 10) Cuneolina/Vercorsella sp., samples DRK35 and DRK16. 

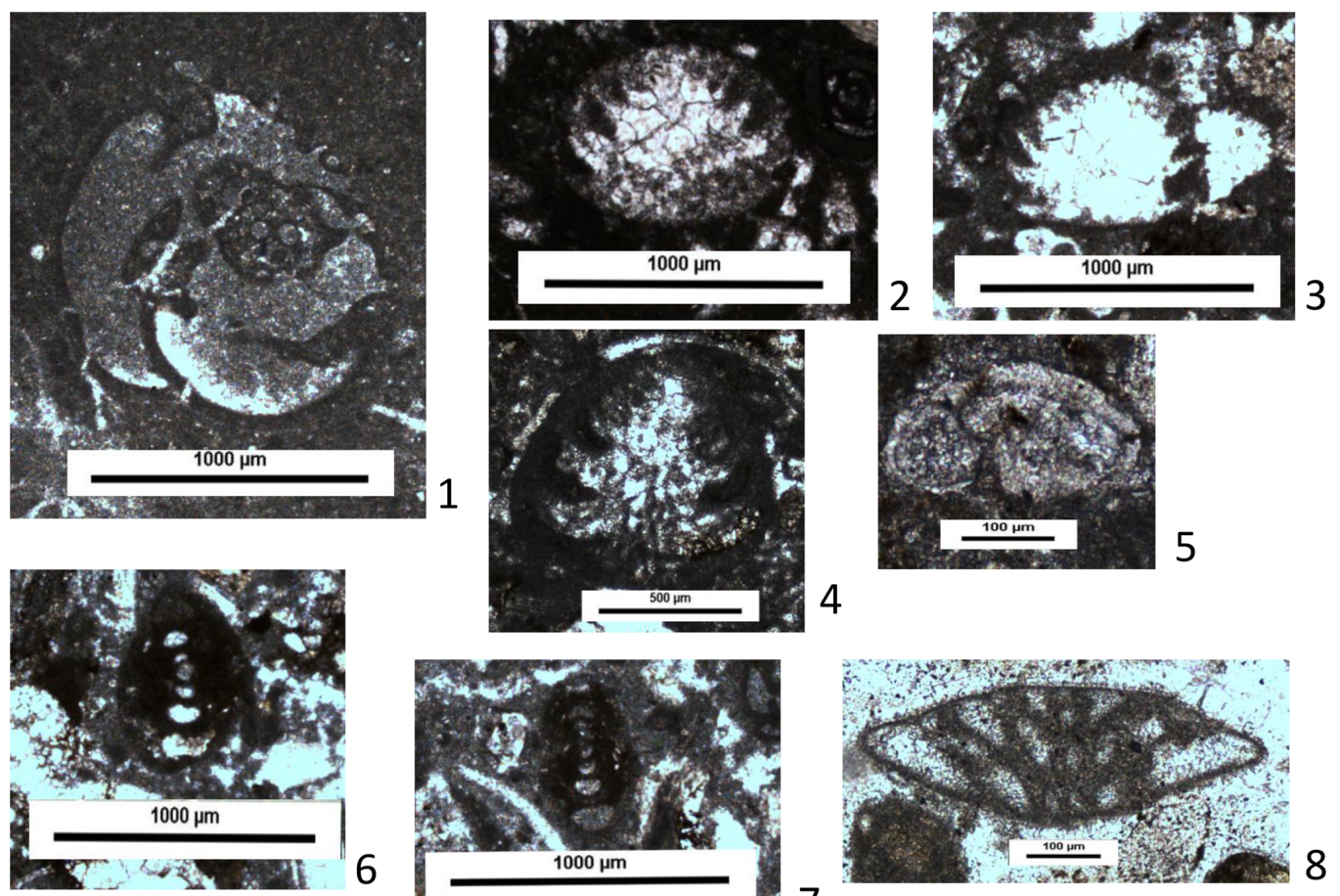

4
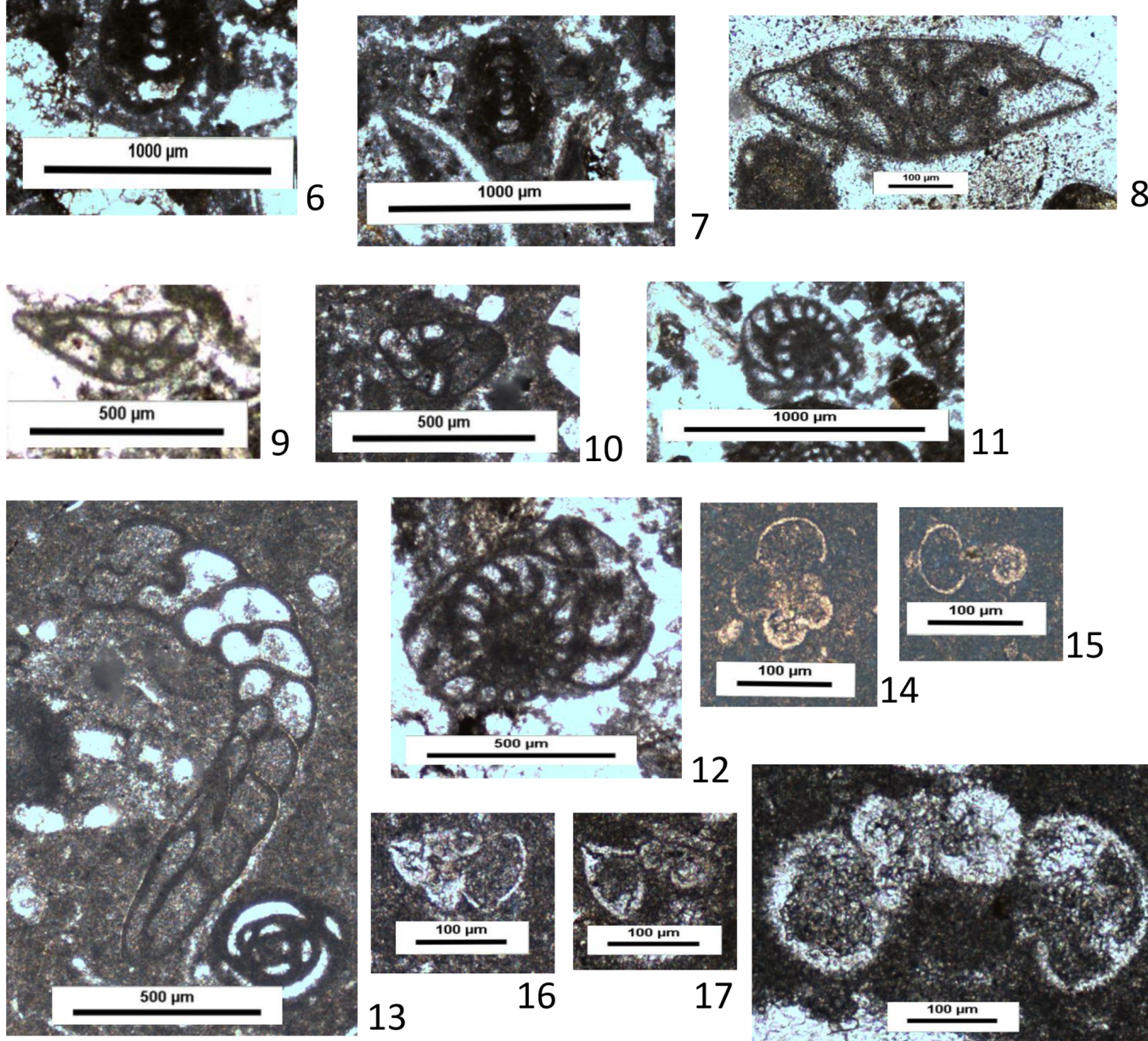

13

17

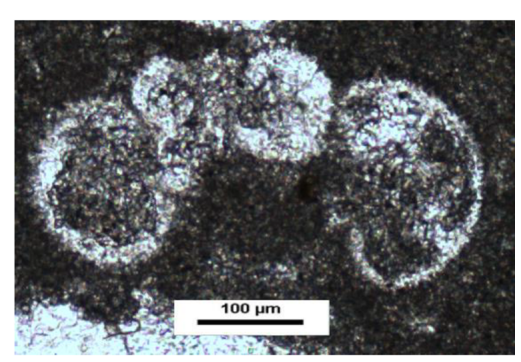

18

Figure 10. Thin-section photographs of benthonic and planktonic foraminifera from the Derdere Formation at Derik: (1) Chrysalidina gradata d'Orbigny, sample DRK40; (2-4) Coscinoconus intermedius (Henson), samples DRK35 (2-3) and DRK10 (4); (5) Rotorbinella mesogeensis (Tronchetti, 1981), sample DRK16; (6-7) Nautiloculina broennimanni Arnaud-Vanneau and Peybernès, samples DRK21 and DRK35; (8-10) Nezzazata simplex Omara, samples DRK23, DRK25, and DRK40; (11-12) Biconcava bentori Hamaoui, samples DRK22 and DRK27; (13) Biplanata peneropliformis Hamaoui and Saint-Marc, sample DRK40; (14-15) indeterminate planktonic foraminifera, sample DRK1; (16-17) Asterohedbergella asterospinosa (Hamaoui), samples DRK28 and DRK36; (18) Whiteinella aprica (Loeblich and Tappan), sample DRK11 (U). 
Trocholina intermedius from the supposed early Cenomanian Maududd Formation of Qatar (Henson, 1947). Believing the original species name to be occupied, Henson (1949) created a new name for this species, Trocholina arabica, by which it has usually been described. Following a comprehensive revision of all trocholinids, Rigaud et al. (2013) transferred the species to Coscinoconus and retained the original species name. Arnaud-Vanneau et al. (1988) considered it to range no younger than early Cenomanian. There are a number of records of this species from across the Arabian Plate, where it appears to be typically associated with late Albianearly Cenomanian strata (sequence K120 sensu Sharland et al., 2001; van Buchem et al., 2011). However, Ettachfini et al. (2005) recorded it, although they did not illustrate it, from Unit $\mathrm{C}$ of the Ben Cherrou Formation of Morocco, which is late Cenomanian based on associated ammonites and planktonic foraminifera. Forms figured by Özkan and Altıner (2019) as Coscinoconus sp. are probably this species.

Very small trochospirally coiled rotaliid foraminifera with an asymmetric lenticular test with a clearly convex smooth spiral side and convex to flat umbilical face occur in sample DRK-16 and can be referred to Rotorbinella mesogeensis (Tronchetti) (Fig. 10.5). This species has been recently redescribed by Piuz and Meister (2013), based on material from Oman and Morocco, and by Rosales and Schlagintweit (2015), based on material from Spain. In the Natih Formation of Oman, it occurs in beds of Cenomanian age. Piuz and Meister (2013) introduced a number of subspecies to capture the range of morphological variation. Our material is too sparse to use that level of taxonomy, although the dimensions of the specimen illustrated here fall within the lower size grouping of $R$. mesogeensis mesogeensis Piuz and Meister. In a number of other samples, indeterminate small rotaliids and discorbids occur, but it is not possible to identify them to genus or species level. R. mesogeensis was not recognised by Özkan and Altıner (2019) in their study of the Derdere Formation, although it may be amongst the indeterminate rotaliids they recognise.

Small forms of Nautiloculina occur sporadically in the lower section of the Derdere Formation (Fig. 10.6-10.7). Only axial sections have been observed with three whorls present and a sub-rounded periphery. Maximum heights (equivalent to equatorial diameter) observed are 0.58, 0.68, and $0.83 \mathrm{~mm}$, and diameters observed (equivalent to thickness) are $0.5,0.48$, and $0.34 \mathrm{~mm}$. Where present the proloculus is $60 \mu \mathrm{m}$ in diameter. These features are in keeping with the type description of Nautiloculina broennimanni Arnaud-Vanneau and Peybernès. Nautiloculina can be distinguished from the superficially similar genus Charentia by its relatively simple wall structure, Charentia having a finely canaliculate "pseudoalveolar" wall. Özkan and Altiner (2019) did not report Nautiloculina in their study of the Derdere Formation.

According to Arnaud-Vanneau and Peybernès (1978) N. broennimanni ranges younger than any other species of $\mathrm{Nau}$ - tiloculina, being known from Albian but not latest Albian strata (although the majority of its records are from Aptian or older strata). It has never been formally recorded from Cenomanian strata, and thus our record extends its range. However, in the Middle East there are other records of Nautiloculina from Cenomanian strata that are also probably this species. These include records from the Sarvak Formation of the Iranian Zagros by Toulabi and Rezaei Roozbahani (2015) and by Afghah et al. (2014) (as Nautiloculina oolithica Mohler and Nautiloculina sp., respectively).

Nezzazatids occur throughout much of the lower Derdere Formation and include Nezzazata simplex Omara (Fig. 10.8-10.10), Biconcava bentori Hamaoui and SaintMarc (Fig. 10.11-10.12), and Biplanata peneropliformis Hamaoui and Saint-Marc (Fig. 10.13).

We regard $N$. simplex as describing relatively low trochospiral forms with a generally plano-convex shape (ca. 0.25 $0.6 \mathrm{~mm}$ diameter in axial section) with a distinct proloculus (ca. $0.05 \mathrm{~mm}$ in diameter), comparable with the small forms described by Rosales and Schlagintweit (2015). $N$. simplex was first recognised from the Cenomanian of the Gulf of Suez region and has subsequently been widely reported from mid-Cretaceous sediments across the Arabian Plate and Mediterranean Tethys (e.g. Rahimpour-Bonab et al., 2012 and Assadi et al., 2016 from the Sarvak Formation of Iran; Al-Dulaimy and Al-Sheikhly, 2013 from the Mishrif Formation of Iraq; Smith et al., 1990 from the Natih Formation of Oman; Ghanem et al., 2012, from the Syrian Palymyrides). Solak et al. (2019) recorded it from Cenomanian strata in the Turkish Taurides. It is a long-ranging species occurring within late Albian-Turonian sediments or even as young as Campanian (Hamaoui, 1985a; Velić, 2007). It was recognised (along with Nezzazata conica (Smout)) within the lower half of the Derdere Formation by Özkan and Altıner (2019). Görür et al. (1991) recorded N. simplex from the Derdere Formation without illustration.

$B$. bentori and B. peneropliformis were first described (Hamaoui and Saint-Marc, 1970) from the middle Cenomanian and Cenomanian-Turonian of Israel and Lebanon and are regularly reported in Cenomanian age sediments from across the Arabian Plate and Mediterranean Tethys (e.g. Rahimpour-Bonab et al., 2012; Solak et al., 2019). Their range is a little uncertain but seems to have been reported mostly from middle and late Cenomanian strata (Hamaoui, 1985b, c). Özkan and Altıner (2019) did not record them in their study of the Derdere Formation.

\subsection{Planktonic foraminifera}

Thin-sections from a number of samples in the studied material contain very small-small (ca. $0.1 \mathrm{~mm}$ diameter) simple globular, trochospiral, planispiral or biserial planktonic foraminifera (Fig. 10.14-10.15). These are difficult to identify with precision in random thin-sections. They can be assigned to the genera Muricohedbergella, Macroglo- 

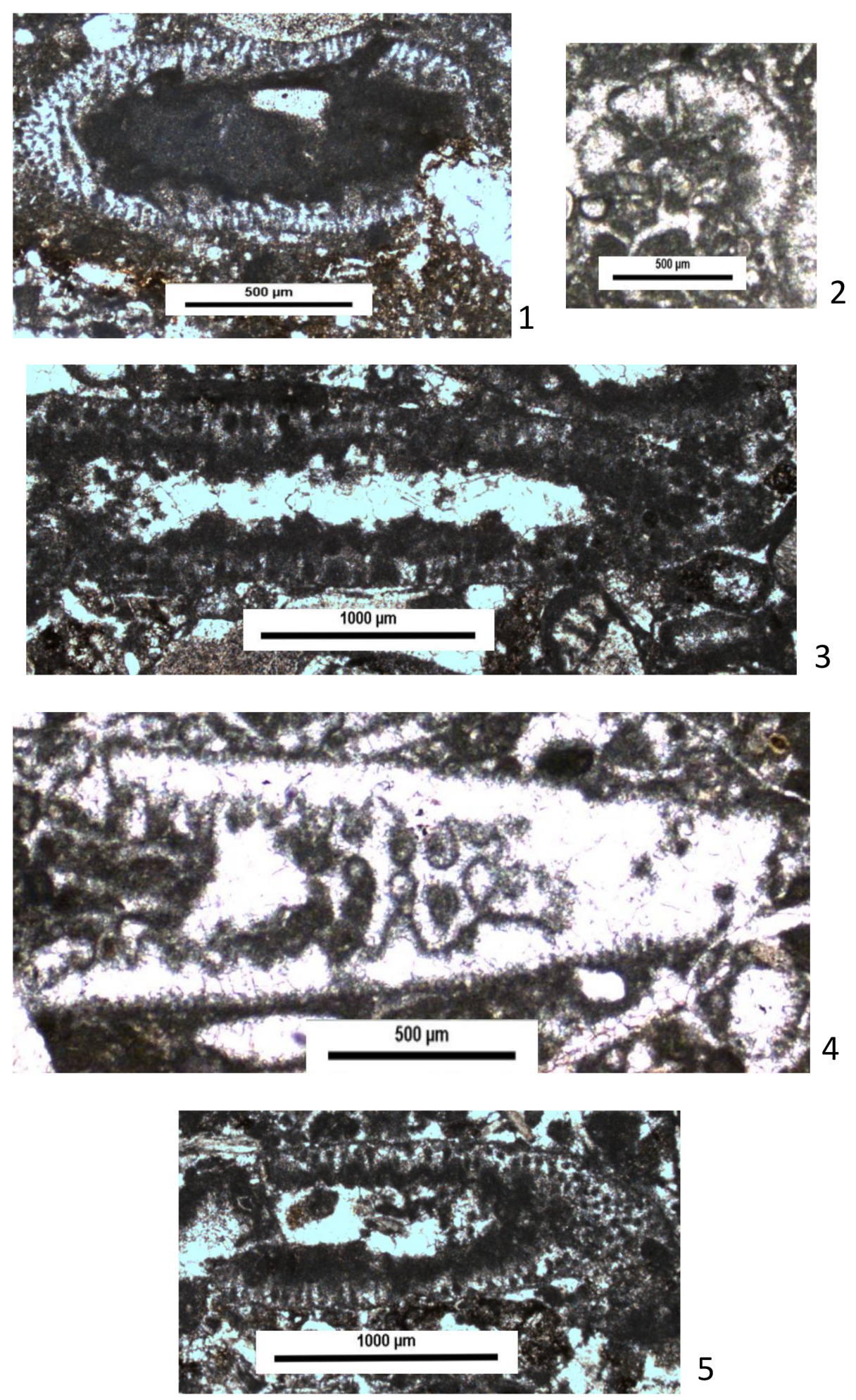

Figure 11. Thin-section photographs of calcareous algae from the Derdere Formation at Derik: (1) Halimeda sp., sample DRK29, and (2-5) Trinocladus tripolitanus Raineri, samples DRK8 (2, 4) and DRK10 (3, 5). 
bigerinelloides and Heterohelix and possibly long-ranging species such as Muricohedbergella delrioensis (Carsey) and Macroglobigerinelloides ultramicrus (Subbotina). Their biostratigraphic value is thus limited, but their presence does indicate open marine depositional conditions and, if common, outer shelf water depths (Hart and Leary, 1990).

In their study of the Derdere Formation, Özkan and Altıner (2019) identified a number of planktonic foraminifera of similar appearance to species level (including M. delrioensis and $M$. ultramicrus). We are unable to reproduce their results with confidence here. In our material, specimens of possible Heterohelix only occur in the upper Derdere Formation, whilst Özkan and Altıner (2019) noted this genus in both the upper and lowermost parts of the Derdere Formation.

A significant planktonic foraminifera within our Derdere Formation samples is A. asterospinosa (Fig. 10.16-10.17). This species is characterised by its planoconvex or concavoconvex profile and tubulospinate extension in the chambers of the final whorl. Our specimens fall within the range of variability of the taxon characterised by their small size (diameter around $110-120 \mu \mathrm{m}$ ), their tubulospinate extension in the chambers of the final whorl, planoconvex profile, early globular-subglobular chambers and rapid increase in chamber size in the last whorl. Originally described from the middle to late Cenomanian of Israel (Hamaoui, 1965), the species has sporadically been recorded from the southern Tethyan margin, including records from the late Cenomanian of Morocco (Ettachfini et al., 2005; Lézin et al., 2012) and Tunisia (Abdallah and Meister, 1997), the middle Cenomanian of western Qatar (El Beialy and Al-Hitmi, 1994), the middle and late Cenomanian of Sinai (Shahin and Elbaz, 2013), and the middle and late Cenomanian Mishrif Formation of Kuwait and southern Iraq (El-Naggar and Al-Rifaiy, 1973; Mahdi and Aqrawi, 2014). Özkan and Altıner (2019) did not record this species in their assessment of the micropalaeontology of the Derdere Formation, but it has previously been reported from the Derdere Formation by Mülayim et al. (2020). Its presence provides calibration of the biostratigraphy of the larger benthonic foraminifera that co-occur with it (i.e. age no older than middle Cenomanian).

The upper Derdere Formation contains relatively common planktonic foraminifera, most of which cannot be identified to species level. One exception is Whiteinella aprica (Loeblich and Tappan) (Fig. 10.18). In thin sections, W. aprica appears as a relatively large (ca. $0.4 \mathrm{~mm}$ maximum diameter), notably globular planktonic foraminifera, with a wide and deep umbilicus and a low trochospire (see, for example, illustrations in Premoli Silva and Verga, 2004). Its presence indicates an age no older than late Cenomanian (Premoli Silva and Verga, 2004), and it is a common component of assemblages around the Cenomanian-Turonian boundary, e.g. within the informal "Zone à Grandes Globigerines" (Leckie, 1985). Özkan and Altıner (2019) did not record the species in their study of the Derdere Formation, although they did record other or indeterminate species of Whiteinella from the upper part of the formation. Mülayim et al. (2019a) recorded and illustrated W. aprica from the lower part of the Karababa Formation that overlies the Derdere Formation.

On the Arabian Plate, W. aprica has been recorded from the Iranian Zagros Mountains (Afghah and Fadaei, 2015), where its co-occurrence with Rotalipora greenhornensis (Morrow) was used to indicate a late Cenomanian age. Ghanem and Kuss (2013) illustrated the species from the late Cenomanian of north-western Syria, with the age constraint being provided by co-occurrence with a variety of other planktonic foraminifera species. Records without illustration include those from the late Cenomanian-early Turonian of Jordan which were age-calibrated by ammonites (Schulze et al., 2004), from the Turonian Kometan Formation of north-eastern Iraq (Jaff et al., 2015), and the Turonian part of the Natih Formation of Oman (Wohlwend et al., 2016). Lipson-Benitah et al. (1997) recorded it from northern Israel in rocks they considered middle Cenomanian but which could be as young as late Cenomanian based on associated fauna.

Whiteinella is classified as an opportunist form of planktonic foraminifera, inhabiting surface waters in thermally stratified oceans (Norris and Wilson, 1998), and hence it is often associated with high productivity at the time of Ocean Anoxic Event 2 (Hart and Leary, 1990). It indicates normal marine salinities in fully open marine conditions.

\subsection{Calcareous algae}

Mid-Cretaceous calcareous algae remain poorly known from the Arabian Plate, with relatively few published records (exceptions include Saint-Marc, 1974, from Lebanon, and Kuss, 1994, from Sinai and Jordan). There are no previous descriptions of calcareous algae from the Derdere Formation in south-eastern Turkey. The records reported herein suggest that with further sampling the occurrences could be reported more fully.

Udoteacean algae occur in the lower part of the lower Derdere Formation (Fig. 11.1). As discussed by Flügel (1988), there are arguments for placing Mesozoic segmented udoteacean algae, preserved as elongate, cylindrical segments, circular in cross section, and possessing a medullary zone of very fine, tangled, non-parallel tubular threads and a cortex of approximately radial fine branching threads, within a loose concept of the extant genus $\mathrm{Hal}$ imeda. Our material from the lower Derdere Formation is insufficient for definitive speciation but does bear comparison with material described as "Boueina cf. hochstetteri Toula" by Kuss (1994) from the Cenomanian of Jordan and Sinai (its diameter of $0.9-1.0 \mathrm{~mm}$ is comparable, for example). $B$. hochstetteri was first described from the Lower Cretaceous of Serbia (see review by Bucur et al., 2018). Other material has some similarity to that described as Boueina pygmaea 
Pia by Kuss (1994), a species originally described from the Cenomanian-Turonian of Libya (Pia, 1936).

Dasycladalean algae occur within the lower Derdere Formation, including Trinocladus tripolitanus Raineri (Fig. 11.2-11.5). Although it is long-ranging (Barattolo, 2002), as noted by Kuss (1994), the species is a common constituent of Cenomanian-Turonian shallow-marine carbonate strata from North Africa and the Middle East. Kuss and Conrad (1991) and Kuss (1994) describe it from Sinai and Jordan. Elliott (1968) and Shirazi (2008) provide other records from Arabia. The external diameter of the species recorded herein $(0.6-0.83 \mathrm{~mm})$ are somewhat larger than the description of the type material as redescribed by Pia (1936) but are in keeping with specimens described by Schlagintweit (1992). Preservation is highly variable, with substantial dissolution typical, as described by Schlagintweit and Wilmsen (2014).

Fragments of calcareous algae referable to the gymnocodiacean Permocalculus are common in part of the upper Derdere Formation section (Fig. 12.1). The small size of the pores present $(0.015-0.07 \mathrm{~mm})$ indicates that these occurrences can be referred to Permocalculus irenae Elliott. This species was originally described from Albian-Cenomanian strata of Iraq (Elliott, 1958). From the Arabian Plate, it has been reported from mid-Cretaceous strata of Kuwait (ElNaggar and Al-Rifaiy, 1972, 1973), Syria (Mouty et al., 2003), Lebanon (Basson and Edgell, 1971), Oman (Simmons and Hart, 1987; Smith et al., 1990), Iran (Shirazi, 2008; Shirazi et al., 2011), and Jordan and Sinai (Kuss and Schlagintweit, 1988; Kuss and Conrad, 1991; Farouk et al., 2017). Although more information to constrain the stratigraphic range of this species would be useful, a number of authors (e.g. Basson and Edgell, 1971; Poignant, 1978; Kuss and Conrad, 1991) indicate that it occurs in strata no younger than Cenomanian. This is important in providing some age constraint on the upper Derdere Formation.

\subsection{Other microfossils}

Micro-coprolites similar to Favreina (e.g. Elliott, 1962; Kuss and Senowbari-Daryan, 1992; Hughes, 2013) occur towards the top of the upper Derdere section (Fig. 12.2). Poor preservation in our material precludes detailed identification.

Calcispheres (most likely the calcareous cysts of certain dinoflagellates; Wendler et al., 2010) occur in variable abundance in the upper Derdere section (Fig. 12.3). Many of specimens encountered seem compatible with Pithonella sphaerica (Kaufmann) and Pithonella ovalis (Kaufmann), which are common and long-ranging species (Dias-Brito, 2000). A late Cenomanian-early Turonian global calcisphere bioevent is associated with Ocean Anoxic Event 2 (Hart, 1991; Wendler et al., 2010), with a high abundance of calcispheres recorded during this interval from many Tethyan margins. Mülayim et al. $(2018,2020)$ have previously recorded Pithonella and other calcispheres from the lowermost (not upper) Derdere Formation of the subsurface, in stratigraphic units not seen in our outcrop study. "Calcisphaerulids" (i.e. calcispheres) were recorded by Özkan and Altıner (2019) from both the lower and upper Derdere Formation at outcrop. An interval with abundance in the uppermost Derdere Formation most likely equates to the interval where we record these fossils.

\section{Biostratigraphic interpretation}

In many of the samples studied, microfossils and especially foraminifera are common. In the lower Derdere Formation larger benthonic foraminifera, especially alveolinids, are a notable component. In the upper Derdere Formation (and parts of the lower Derdere Formation), planktonic foraminifera are present. Both foraminiferal groups provide useful biostratigraphic calibration and age interpretation.

In the lowest part of the studied lower Derdere Formation section, samples DRK1-DRK6 contain only long-ranging Cretaceous planktonic foraminifera or are barren of fauna. This part of the section is thus of indeterminate age, although given the middle Cenomanian age of the overlying section is probably also Cenomanian in age.

The lower Derdere Formation section, comprising samples DRK7-DRK37, contains an often rich and reasonably diverse fauna of foraminifera and calcareous algae, which indicate a middle Cenomanian age. Important taxa (see Sect. 6 for a discussion of stratigraphic significance of specific microfossil species) in order of observed inception include the following.

- D. oblonga - middle Cenomanian at its type locality but may range longer as many Arabian records of $P$. tenuis may in fact be this species.

- P. arabica - middle-early late Cenomanian based on original description, although this range may be extended as many Arabian records of $P$. cretacea may in fact be this species.

- Indeterminate orbitolinids - if Orbitolina sensu lato is present amongst these, then an age no younger than middle Cenomanian is indicated.

- C. cuvillieri - no younger than middle Cenomanian.

- B. bentori - middle to late Cenomanian.

- A. asterospinosa - indicative of age no older than middle Cenomanian age.

Within this interval are taxa that have not previously been described from sediments as young as middle Cenomanian. These include $C$. intermedius (previously thought to be no younger than early Cenomanian) and $N$. broennimanni (previously thought to be no younger than Albian). The undoubted middle Cenomanian aspect to this section suggests the stratigraphic ranges of these taxa should be extended. 

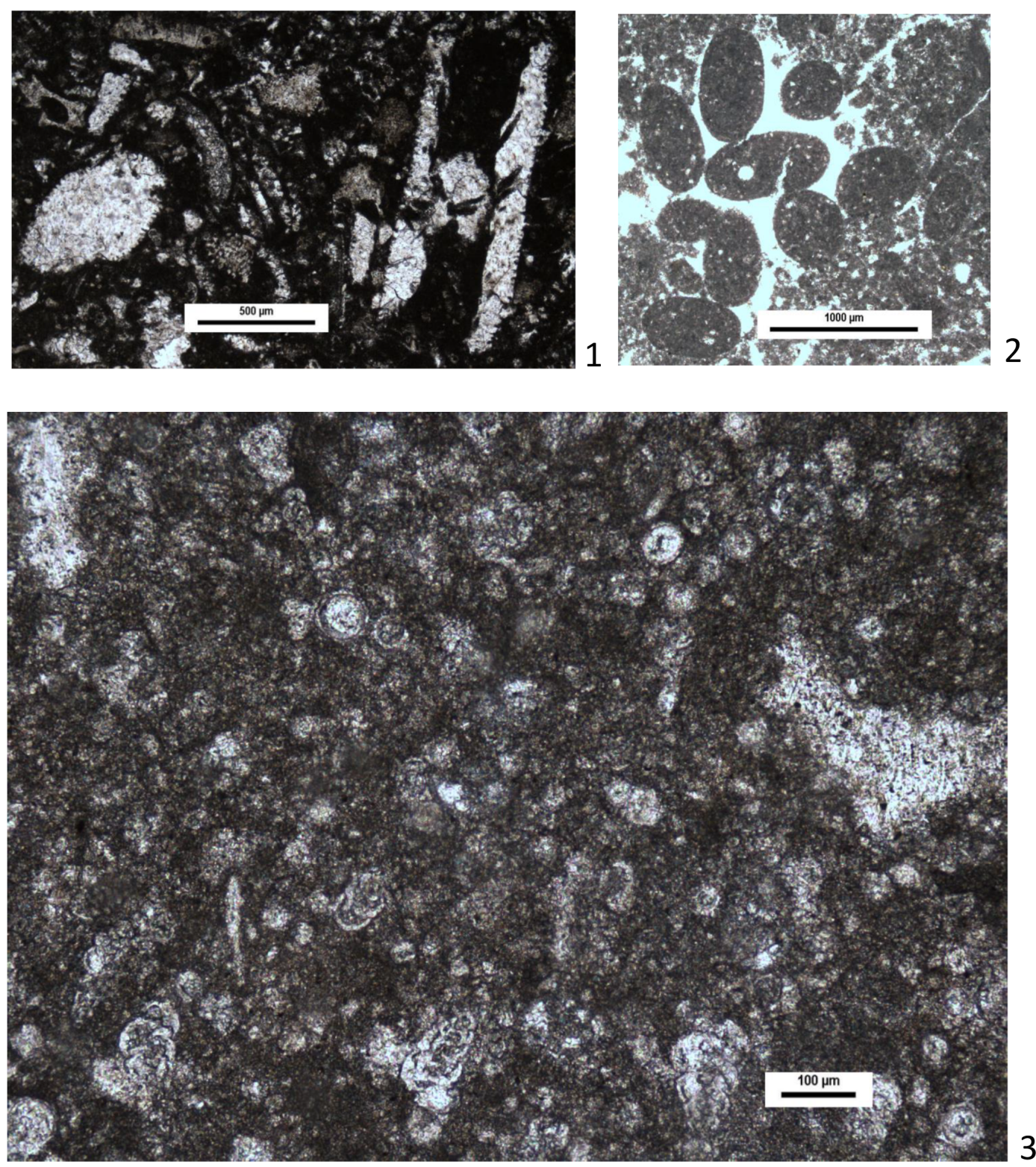

Figure 12. Thin-section photographs of calcareous algae and other microfossils from the Derdere Formation at Derik. (1) Permocalculus irenae Elliott, sample DRK3(U); (2) micro-coprolites, sample DRK12(U); (3) calcispheres and indeterminate planktonic foraminifera, sample DRKA10.

Samples DRK38-DRK40 can only be assigned a generalised middle-late Cenomanian age, given the presence of $C$. gradata, $B$. bentori, and $B$. peneropliformis.

Samples DRK41-DRK50 contain no stratigraphically useful microfauna or microflora and are thus of indeterminate age.

The upper Derdere Formation contains few stratigraphically significant taxa. The most useful are rare occurrences of the planktonic foraminifera W. aprica in sample DRK$11(\mathrm{U})$. This species is common around the CenomanianTuronian boundary and indicates that this part of the studied section is no older than late Cenomanian and no younger than Turonian (Premoli Silva and Verga, 2004). Lower in the upper Derdere Formation section, samples DRK-2(U)DRK-4 (U) contain the alga P. irenae. These samples are unlikely to be younger than Cenomanian (presumably middlelate Cenomanian, based on the age of the underlying Lower Derdere section).

Overall, much of the lower Derdere Formation in the studied section appears to be middle Cenomanian in age, whilst the upper Derdere Formation has indications of late Cenomanian to Turonian age, although distinctly Turonian marker taxa are absent. The notion that Derdere Formation at Derik is most likely middle-late Cenomanian age supports the ob- 
servations of Mülayim et al. (2019a, b) that with the base of the overlying Karababa Formation being associated with the Cenomanian-Turonian boundary event, the Derdere Formation should be restricted to a Cenomanian age, contrary, for example, to the view of Özkan and Altıner (2019). However, the caveat should be noted that in our studied section, the contacts of the Derdere Formation with overlying and underlying units, although close, are not seen, meaning that such an assertion cannot be unequivocal. Furthermore, the boundary between the Derdere and Karababa formations may, at a regional scale, be diachronous. This would match observations in other parts of the Arabian Plate, where the top of the platformal Sarvak Formation of the Iranian Zagros, is, for example, of variable age and may pass into deep-water facies within the Cenomanian or within the Turonian, a probable consequence of local tectonics (e.g. Sharp et al., 2010).

Özkan and Altıner (2019) described the lowermost part of the Derdere Formation as being of Albian age (placing the boundary between the Sabunsuyu and Derdere Formations within "the late middle Albian"). Their evidence for this included a shallow marine benthonic foraminifera assemblage at the base of the Derdere Formation (not seen by us) including Hensonina lenticularis (Henson) and S. quintanensis, overlain by an open marine facies including the planktonic foraminifera Muricohedbergella rischi (Moullade) and Muricohedbergella albiana (BouDagher-Fadel). This is presumably the open marine facies we recognise at the base of the formation, which we regard as being of indeterminate age (although overlain by middle Cenomanian strata), since we do not regard the planktonic foraminifera present as being assignable to species-level identification.

Notwithstanding the difficulties of identifying simple planktonic foraminifera to species level in thin sections, we would also question the Albian age assignment on other grounds. S. quintanensis was first described from the Cenomanian (Vicedo et al., 2011), whilst the record of H. lenticularis is, in our view, questionable. Arnaud-Vanneau et al. (1988) and Schlagintweit and Piller (1990) demonstrated that the original description of Trocholina lenticularis Henson (an asymmetric trochospiral form), differs from that used by Moullade and Peybernès (1974) to define the genus Hensonina (a symmetric planispiral form, synonymous with Involutina hungarica (Sido)). Hensonina lenticularis is thus a nomen nudem, and taxa described as such should probably be referred either to T. lenticularis or to I. hungarica (Consorti et al., 2014). The specimens illustrated by Özkan and Altiner (2019) as "Hensonina lenticularis" are poorly preserved, and difficult to identify with any confidence, but appear to conform better with T. lenticularis sensu Henson (1947) and Arnaud-Vanneau et al. (1988). This species can range into the Cenomanian and was recently placed in the new genus Hensonipapillus by Schlagintweit et al. (2015) (see also Rosales and Schlagintweit, 2015). Finally, Özkan and Altıner (2019) mention (but do not illustrate) the occurrence of $P$. infracretacea in the lowermost Derdere Forma- tion. Whilst this species is, sensu stricto, no younger than Albian, transitional forms to Dukhania conica Henson and C. gradata are known from the Cenomanian (Banner et al., 1991).

Özkan and Altıner (2019) describe a $20 \mathrm{~m}$ interval within the Derdere Formation as having a rich fauna of alveolinids, along with other benthonic foraminifera indicating an undifferentiated Cenomanian age. This must correspond with much of the lower Derdere Formation studied by us, which we would regard as mostly middle Cenomanian. It should be noted that although there are some similarities in the microfossil taxa recognised, we recognise a range of different species, not least because we use the updated alveolinid taxonomy of Vicedo and Piuz (2017), and we recognise a new species.

Both we and Özkan and Altıner (2019) recognise that the upper Derdere Formation contains an interval with common planktonic foraminifera (including species of Whiteinella and Heterohelix) indicating open marine depositional conditions, before shallowing up at the top of the formation to include sediments with abundant miliolids. We would both agree that these units lie close to the Cenomanian-Turonian boundary in age, but we have found no definitive Turonian indicators. On the other hand, Özkan and Altıner (2019) noted the occurrence of the planktonic foraminifera Heterohelix globulosa Ehrenberg and the benthonic foraminifera "Montcharmontia cf. apenninica (De Castro)", which they regard as good evidence for a Turonian age for the upper part of the Derdere Formation. Such an interpretation, it should be noted, challenges the notion that drowning unconformity at the base of the overlying Karababa Formation corresponds to the Cenomanian-Turonian boundary event (Mülayim et al., 2019a, b). In any event, $H$. globulosa and morphologically similar taxa have been reported from Cenomanian strata (Georgescu and Huber, 2009, see also http://www.mikrotax.org/system/index.php?taxon= Planoheterohelix_globulosa\&module=pf_mesozoic, last access: 31 October 2020), whilst the forms described as $M$. cf. apenninica are poorly preserved and hard to assign to this species with confidence (we note the use of "cf."). Additionally, Montcharmontia has been occasionally found in Cenomanian strata (e.g. Piuz et al., 2014).

\section{Palaeoenvironmental interpretation}

The Derdere Formation has long been considered to represent deposition on a carbonate ramp (e.g. Görür et al., 1991; Cros et al., 1999; Robertson et al., 2016; Mülayim et al., 2018, 2019a, b, 2020; Özkan and Altıner, 2019), especially given the lack of any major bioherms. The ramp may have been distally steepened in a north-westerly direction, towards the Neotethys margin as more open marine, organic-rich facies occur there (e.g. Çelikdemir et al., 1991; Demirel and Guneri, 2000). This is supported by regional thinning of the 
succession to the north-west, as documented in an isopach map (Görür et al., 1991; Çelikdemir et al., 1991).

Cater and Gillcrist (1994) provided an initial assessment of deposition setting of the Derdere Formation in the Derik region. They noted that the lower part of the formation (their Member 1) reflects open marine conditions and then rapidly shallows up into a variety of shallow marine settings, often with bioclastic sands, shallowing-up cycles being capped by karst (Members 2-4). They note that the upper part of the formation (their Member 5) at this location reflects a further deepening and further shallowing prior to a hiatus and the subsequent Karababa Formation deposition. This pattern coincides with our interpretation of the Derdere Formation that two deep-water units bracket the majority of the formation that reflects primarily shallow-water platform interior deposition.

Özkan and Altıner (2019) drew similar conclusions. They recognised that the lower part of the Derdere Formation consisting of mudstones and wackestones with planktonic foraminifera represents outer ramp deposition. This rapidly passes up through mid-ramp facies and inner-ramp facies before a marked return to outer-ramp facies in the upper Derdere Formation before a rapid shallowing into peritidal facies.

Our interpretation of the depositional evolution of the Derdere Formation at Derik is as follows.

- The initial part of the succession (Samples DRK1-3) consisting of bioturbated mudstones-wackestones with a sparse fauna of planktonic foraminifera and echinoderm debris (Fig. 5a) represents deposition in a low energy outer ramp setting, below storm wave base, given the lack of transported allochems, scouring, or graded bedding.

- Wackestones and packstones with calcareous algae, discorbids and alveolinid foraminifera (Samples DRK6-8, Fig. 5b-c), and a capping hardground represent deposition in rapidly shallowing inner-ramp environment. Dasycladalean algae such as Trinocladus thrive in very shallow marine waters, requiring red wavelengths of light in their photosynthetic process, which rarely penetrate more than a few metres in seawater (Banner and Simmons, 1994). Alveolinids are also typical of very shallow waters (e.g. Hohenegger, 2011), whilst discorbids often exhibit an epiphytic mode of life.

- Samples DRK9-28 consist of cycles that typically begin with grainstones containing alveolinids, calcareous algae, and echinoderm and rudist bivalve fragments (Fig. 5d, g), passing up into burrowed wackestonespackstones (Fig. 5e) with echinoderm debris and a variety of benthonic foraminifera). Cycles are typically on the scale of a few metres and may be capped by hardgrounds, microkarst, or possibly rootlet horizons
(Fig. 5f). This can be interpreted as high-energy carbonate sand shoals within the inner ramp, overlain by lagoonal deposits that shallow-up towards exposure or depositional hiatus. Such cyclicity may be autocyclic in origin (e.g. shifting foci of shoal location) and/or driven by allocyclic forcing (e.g. high-frequency changes in base level).

- Samples DRK29-37 represent a deepening to more open marine mid-ramp to outer-ramp facies with the presence of bioclastic-peloidal wackestones with some planktonic foraminifera (Fig. 6a-b). Occasional interbeds of relatively coarse bioclastic packstone (Fig. 6.3) may represent storm reworking of inner-ramp components offshore.

- Samples DRK38-50 represent a rapid return to inner-ramp and peritidal depositional conditions with the presence of fenestral mudstones (Fig. 6.4) with micro-coprolites, birds-eye vugs and mud cracks, or dolosparites.

- Much of the upper Derdere Formation represents outerramp facies, with dolomitised mudstones and wackestones alternating with non-dolomitised beds with variable abundance of bioclasts, mostly planktonic foraminifera and calcispheres (Fig. 6.5-6.7). Only at the very top of the formation is there a shallowing to gastropod-rich wackestones, suggestive of inner ramp.

- The sparse planktonic foraminifera assemblages through the succession are characterised by primitive, small opportunistic taxa ( $r$ selection), which indicate unsuitable conditions for planktonic foraminifera probably caused by insufficient depth given the absence or rareness of complex ( $k$-selected specialists) morphotypes (Hart and Bailey, 1979; Caron and Homewood, 1983; Hart, 1999; Petrizzo, 2002).

In terms of major transgressive-regressive events, three significant flooding surfaces may be postulated, as defined by changes in microfacies and abundance of open marine fauna (e.g. planktonic foraminifera).

- In the lowermost part of the Derdere Formation (close to sample DRK1) of uncertain but probable Cenomanian age.

- Within the lower Derdere Formation (close to sample DRK30) of middle Cenomanian age.

- Within the upper Derdere Formation (close to sample DRKA10) of middle-late Cenomanian age. 


\section{Discussion}

\subsection{Stratigraphic patterns}

A number of workers have related the stratigraphic patterns in the Mardin Group or Derdere Formation to eustatic or at least regional relative sea level changes (e.g. Cater and Gillcrist, 1994; Görür et al., 1991; Mülayim et al., 2016, 2019a; Özkan and Altıner, 2019). However, such comparisons are hindered by a lack of precise biostratigraphic control.

Özkan and Altıner (2019) and Yetim and Altıner (2019) argued that 21 depositional sequences could be recognised in the Aptian-Turonian interval within the Mardin Group (including 12 within the Derdere Formation) and argued that these could be correlated with global cycle charts, notably that of Haq (2014), who has presented a view on Cretaceous eustasy (see also Sames et al., 2016). Notwithstanding the uncertainties within the Haq (2014) synthesis as discussed by Ray et al. (2019) and Simmons et al. (2020), we have found that the Derdere Formation biostratigraphy (both that reported herein and that published by Özkan and Altıner, 2019) lacks the precision to confirm a relationship to global patterns. Furthermore, Özkan and Altıner (2019) regard changes in lithology and bed thickness to have been driven solely by allocyclic processes such as eustasy. Whilst that may eventually prove to be true, without detailed study of the changes through techniques such as time series analysis, autocyclic processes (i.e. the lateral shift of facies belts within complex inner-ramp setting) cannot be discounted.

Nonetheless, as described above, we do recognise three significant flooding events within the overall Derdere Formation succession. It would be tempting to correlate these with the three regional, most likely eustatic (Frans van Buchem, personal communication, 2020), Arabian Plate Cenomanian maximum flooding surfaces (MFS) recognised by Sharland et al. (2001) and updated by van Buchem et al. (2011) (K120, K130, K140 MFS), but the chronostratigraphic precision to do so is lacking.

The regional Cenomanian sequence stratigraphy is very clearly expressed in the eastern part of the Arabian Plate in Oman and Iran. Van Buchem et al. (2011) reported that K120 MFS is of early Cenomanian age, with its highstand extending into the early middle Cenomanian. K130 MFS is of middle Cenomanian age with an associated underlying distinctive sequence boundary (SB) within the early part of the middle Cenomanian (see also van Buchem et al. 1996; Schulze et al, 2003, 2004, 2005; Bauer et al., 2003; Homewood et al., 2008; Saber et al., 2009; Razin et al., 2010; Hajikazemi et al., 2010; Grélaud et al., 2010; Hollis, 2011; Ghanem et al., 2012; Rahimpour-Bonab et al., 2012; Ghanem and Kuss, 2013; Wilmsen and Nagm, 2013; Assadi et al., 2016, for examples of this event across the Arabian Plate). Correlation with the global mid-Cenomanian sea level low (Hancock, 2004; Gale et al., 2008) and 95.5 Ma sequence boundary of Haq (2014) seems likely. The prominent hardground and possible exposure surface between samples DRK8 and DRK9 that is middle Cenomanian in age may correspond with K130 SB. Alternatively, it may lie at the exposure surface between samples DRK28 and DRK29 and a shift from inner-ramp facies to deeper facies (also middle Cenomanian).

K140 MFS is high within the Cenomanian, close to the Cenomanian-Turonian boundary, with its highstand possibly extending into the earliest Turonian (van Buchem et al., 2011). Within the Sarvak Formation of the Iranian Zagros, Razin et al. (2010), Vincent et al. (2015), Assadi et al. (2016), and Kalanat and Vaziri-Moghaddam (2019) also recognised three major Cenomanian depositional sequences, whilst Schulze et al. (2005) reported three major Cenomanian sequences from Jordan.

Mülayim et al. (2019a) recognise a maximum flooding surface (MFS) near the base of the Karababa Formation, which they believe contributed to the demise of the Derdere carbonate platform. They associate this MFS with the K140 MFS recognised across the Arabian Plate by Sharland et al. (2001). They regarded this MFS as earliest Turonian in age, although van Buchem et al. (2011) recalibrated the age to within the latest Cenomanian, based on a reassessment of the reference sections in Oman. On the other hand, Mülayim et al. (2019a) suggest that K140 is younger, placing it within the lower part of the middle Turonian (nannofossil zone CC12). It is unclear as to why Mülayim et al. (2019a) made this assessment since the biostratigraphic data associated with the expression of the local MFS (their sample IND-22) is not distinctly middle Turonian, instead indicating an early-middle Turonian age range. Nonetheless, Vincent et al. (2015) considered K140 MFS of (early) Turonian age, and numbered their three Cenomanian sequences K120, $\mathrm{K} 125$, and K130. There is clearly an early-middle Turonian MFS in southern Tethys stratigraphy (e.g. Bauer et al., 2003; Schulze et al., 2003; Wilmsen and Nagm, 2013). Its naming is a point of discussion outside the scope of the current paper, but we contend that it does not occur within the Derdere Formation, at least not at this locality and in those studied by Mülayim et al. (2019a, b). As noted previously, at a regional scale, a diachronous age to the top of the Derdere Formation cannot be discounted.

If the Derdere Formation does not extend into the Turonian, as seems likely from the data presented by Mülayim et al. (2019a), there are contrasts with other mid-Cretaceous carbonate platform successions elsewhere on the Arabian Platform. For example, in Jordan (Schulze et al., 2003, 2004, 2005), Sinai (Bauer et al., 2003; Saber et al., 2009), Kuwait (El-Naggar and Al-Rifaiy, 1973), Lebanon (Saint-Marc, 1974), the Iranian Zagros (e.g. Rahimpour-Bonab et al., 2012; Vincent et al., 2015; Navidtalab et al., 2019; Kalanat and Vaziri-Moghaddam, 2019), and Oman (Droste and van Steenwinkel, 2004; Homewood et al, 2008; Wohlwend et al., 2016), there is reasonable evidence for Turonian carbonate platform deposition. A diachronous ending of mid- 
Cretaceous carbonate platform deposition may reflect different timing of tectonic effects associated with the closure of Neotethys (Stampfli and Borel, 2002; Vérard et al., 2015).

\subsection{Palaeobiogeography}

The microfossils present within the Derdere Formation at Derik contain elements that are widely recognised in Cenomanian strata across the Arabian Plate. Favourable comparisons can be made to assemblages recognised in the Natih Formation of Oman (e.g. Simmons and Hart, 1987; Smith et al., 1990; Vicedo and Piuz, 2017), the Sarvak Formation of the Iranian Zagros (e.g. Sampo, 1969; Rahimpour-Bonab et al., 2012; Assadi et al., 2016), the Maududd-Mishrif Formations of the Arabian Gulf (e.g. El-Naggar and Al-Rifaiy, 1972, 1973), and the succession in Lebanon (e.g. Saint-Marc, 1974). Perhaps not surprisingly, the succession of Cenomanian microfossils in Syria (Ghanem et al., 2012; Ghanem and Kuss, 2013) shows strong similarities, especially in the light of taxonomic revisions that could be made to the identifications by these authors. Moreover, even though it is on the other side of Tethys, there are similarities with the Cenomanian succession in the Taurides (e.g. Y1lmaz, 1999; Sarı et al., 2009; Solak et al., 2019).

Of particular note is the occurrence of alveolinids that had previously only been recognised in the eastern part of the Arabian Plate, in Oman and Socotra (e.g. Vicedo and Serra-Kiel, 2011; Vicedo and Piuz, 2017). This includes the genus Decastroia (represented by D. oblonga) and species of Praealveolina ( $P$. cf. arabica). Their occurrence in the Derdere Formation demonstrates that these taxa occur across a broad range of the Arabian Plate from southern Turkey in the far north-west to Oman in the far south-east. It is anticipated that taxonomic revision of other mid-Cretaceous alveolinid occurrences from other parts of the plate, including from the Zagros and Arabian Gulf, will demonstrate the widespread occurrence of these taxa, often erroneously described as $P$. tenuis, $P$. cretacea, etc. Vicedo and Piuz (2017) suggested that endemism might be present with mid-Cretaceous alveolinids, with taxa specific to the Arabian Plate or perhaps the southern margin of Neotethys, this fauna being distinct from that in, for example, western Europe and the northern margin of Neotethys. The presence of a new species of Simplalveolina in the Derdere Formation (S. mardinensis n. sp.) may offer some support to the notion that there are indeed endemic elements to Arabian Plate midCretaceous larger benthonic foraminiferal fauna. In addition to alveolinids, Schlagintweit and Yazdi-Moghadam (2020) have noted Arabian endemism in mid-Cretaceous orbitolinids.

The age range of the benthonic foraminifera and dasycladalean algae in the mid-Cretaceous of Tethys remains the topic of ongoing research, as independent age control (e.g. from ammonites or stable isotopes) is often lacking. In the Derdere Formation, the co-occurrence of benthonic foraminifera with planktonic foraminifera helps provide a degree of constraint on the stratigraphic range of a number of widely recognised benthonic foraminifera species.

\section{Conclusions}

Thin sections of samples of the mid-Cretaceous Derdere Formation (Mardin Group) from outcrops close to the town of Derik in south-eastern Turkey contain rich and diverse micropalaeontological assemblages. Larger benthonic foraminifera, planktonic foraminifera, and other microfossils, including calcareous algae, are present, and the overall assemblages are similar to those from other parts of the Arabian Plate and the southern Tethyan margin of Gondwana.

Alveolinid foraminifera are particularly common and can be described using the taxonomic concepts of Vicedo and Serra Kiel (2011), Piuz et al. (2014) and Vicedo and Piuz (2017), who have recognised that many alveolinids occurring in the mid-Cretaceous of Arabia are distinctive and should be placed in separate, probably endemic, genera and species. For example, we recognise $D$. oblonga and $P$. cf. arabica taxa that might previously been placed within $P$. tenuis and P. cretacea. We also recognise a new species, $S$. mardinensis, a distinctive Simplalveolina with small proloculus.

In contrast to some previous studies (e.g. Özkan and Altıner, 2019), the majority of the section can be demonstrated to be Cenomanian, notably middle Cenomanian, in age, with no confirmation of extension into the Albian or Turonian. The very lowest part of the formation studied by us is of indeterminate age based on the microfossils present, but given the middle Cenomanian age of the overlying part of the section it is unlikely to be older than Cenomanian. Confirmation of age no older than middle Cenomanian for much of the formation is provided by the co-occurrence of the planktonic foraminifera A. asterospinosa with a variety of benthonic foraminifera, including the alveolinid species and taxa such as $C$. gradata. In the upper part of the formation, the occurrence of planktonic foraminifera such as W. aprica, along with calcareous algae such as $P$. irenae, suggests an age no older than late Cenomanian. A Turonian age cannot be completely excluded, but no positive evidence for a Turonian age was noted. Such conclusions are in keeping with, for example, the view of Mülayim et al. (2019a, b) that the Derdere Formation is wholly Cenomanian in age, based on carbon isotope stratigraphy and the age of the overlying Karababa Formation. At a regional scale, we cannot exclude the possibility of diachronous formation boundaries as is seen within the mid-Cretaceous of other parts of the Arabian Plate.

Deposition of the Derdere Formation at Derik took place on a carbonate ramp within a range of discrete deposition settings ranging from peritidal to outer ramp. A notable feature are the small-scale cycles within inner-ramp facies that typically begin with grainstones containing alveolinids, calcare- 
ous algae, echinoderm, and rudist bivalve fragments, passing up into burrowed wackestones-packstones, with echinoderm debris and a variety of benthonic foraminifera. Cycles are typically on the scale of a few metres and may be capped by hardgrounds, microkarst, or possibly rootlet horizons. These cycles can be interpreted as high-energy carbonate sand shoals within the inner ramp, overlain by lagoonal deposits that shallow up towards exposure or depositional hiatus. Such cyclicity may be autocyclic in origin (e.g. shifting foci of shoal location) or driven by allocyclic forcing (e.g. high-frequency changes in base level).

Three major deepening events are recognised within the succession, characterised by more open marine microfauna (abundance of planktonic foraminifera and calcispheres) and microfacies (pelagic bioclastic mudstones and wackestones). These occur at the base of the formation (uncertain age, but no younger than middle Cenomanian), within the middle Cenomanian lower part of the formation, and towards the top of the formation (no older than late Cenomanian). These may correlate with three Cenomanian deepening phases seen in other parts of the Arabian Plate (van Buchem et al., 2011). A probable exposure surface in the lower part of the formation may correspond with the widely recognised Arabian Plate middle Cenomanian K130 sequence boundary (van Buchem et al., 2011 and numerous other references cited in Sect. 9). However, biostratigraphic precision remains insufficient to confirm the expression of the classic Arabian Plate sequence stratigraphic model of Sharland et al. (2001) and its updates (e.g. van Buchem et al., 2011). 
Appendix A: Systematic palaeontology (Michael D. Simmons and Vicent Vicedo)

Phylum Foraminifera d'Orbigny

Class Tubothalamea Pawlowski, Holzman and Tyszka

Order Miliolida Delage and Hérouard

Suborder Miliolina Delage and Hérouard

Superfamily Alveolinoidea Ehrenberg

Family Praealveolinidae Fleury and Fourcade

Subfamily Praealveolininae Vicedo and Piuz

Genus Simplalveolina Reichel

Type species Praealveolina simplex Reichel

Simplalveolina mardinensis $\mathrm{n}$. sp. Simmons and Vicedo

2017 Simplaveolina gr. simplex (Reichel, 1936). Vicedo and Piuz, fig. 17.H-L

\section{Etymology}

From the town of Mardin, close to the type locality in southern Turkey.

\section{Material}

Non-orientated (random) thin sections from samples of cemented carbonates: samples DRK9, DRK22, DRK23, DRK24, DRK27, DRK29, and DRK31; questionable in samples DRK10, DRK13, DRK14, DRK15, DRK21, DRK28, DRK30, DRK32, and DRK35.

\section{Types}

The holotype is the specimen illustrated in Fig. 7.1 (deposited in the Museum of Department of Geological Engineering, Middle East Technical University, Ankara, Turkey; accession number P/S-C 0045a; sample DRK29); the other specimens illustrated in Fig. 7 are paratypes (also deposited in the Museum of Department of Geological Engineering, Middle East Technical University, Ankara, Turkey; accession number P/S-C 0045b-e). Species registered in Zoobank on 1 November 2020 (registration: zoobank.org:act:804730B6D1DA-42E9-8BCB-70ED64D303EC).

\section{Type horizon and locality}

Lower Derdere Formation, just to the north of the town of Derik, close to the city of Mardin in south-eastern Turkey (middle Cenomanian).

\section{Diagnosis}

Porcellanous, globular test with planispiral chamber arrangement. Multiple apertures, forming a single row of 40 small openings on the apertural face. Megalospheric generation characterised by a small proloculus of about $85-105 \mu \mathrm{m}$, followed by a short flexostyle. Chamber lumen subdivided by septula into tubular chamberlets. Chamberlets of the same chamber connected by a preseptal passage. Septula of following chambers aligned. Diameter of adult shell of $0.8-1.1 \mathrm{~mm}$ with 8-9 whorls.

\section{Description}

The megalosphere is sub-spherical with a flexostyle that covers a quarter of a whorl. In axial subsection of adult shells, the morphology of the chamberlets is sub-rectangular. The endoskeleton is composed of septula and a very thin basal layer. Septula are aligned from chamber to chamber and are only interrupted by the preseptal passage that runs from pole to pole. The shell only shows one row of chamberlets, there are no floors or other similar structural elements or partitions. The number of chamberlets in a quarter of the fourth whorl is around 9-10. Microspheric generation has not been convincingly observed. Among the specimens studied, there are some megalospheric forms that show a proloculus with a larger diameter, of around $200 \mu \mathrm{m}$ (Fig. 8.1-8.2). The scarce number of specimens of this type - only two of them have been found - has not allowed us to specify whether they correspond to a trimorphic generation or they belong to juvenile specimens of $S$. simplex.

\section{Remarks}

The species ascribed to Simplalveolina are simple, globular alveolinids with no supplementary chamberlets, which is the main diagnostic criterion to differentiate them from other representatives of the Praealveolininae, such as the species of the genus Praealveolina Reichel (type species $P$. tenuis Reichel 1933). Furthermore, the absence of medullar chamberlets are the main difference between Simplalveolina and the group Decastroinae Vicedo and Piuz. S. mardinensis n. sp. differs from the type species, S. simplex, by having a smaller proloculus $(85-105 \mu \mathrm{m}$ vs. $110-200 \mu \mathrm{m}$, respectively) and smaller axial diameters of adult shells, which also show fewer whorls $(0.8-1 \mathrm{~mm}$ with $8-9$ whorls vs. $1.3-2 \mathrm{~mm}$ with 8-12 whorls, respectively).

\section{Distribution}

In addition to records from the middle Cenomanian part of the Derdere Formation in south-eastern Turkey, S. mardinensis $\mathrm{n}$. sp. is present in the middle Cenomanian part of the Natih Formation in the Oman Mountains, where some specimens described as "Simplalveolina gr. simplex" (Vicedo and Piuz, 2017) can be assigned to this new species. 
Data availability. All data generated in this study are included within this paper. Sample material, including thin sections, is held in the Museum of Department of Geological Engineering, Middle East Technical University, Ankara, Turkey.

Author contributions. The study concept was developed by İÖY and MDS. Samples were collected by İÖY, İH and OM. Micropalaeontological and microfacies analysis was carried out by MDS, VV, and BS. The article was written by MDS, VV, and İÖY.

Competing interests. The authors declare that they have no conflict of interest.

Acknowledgements. Felix Schlagintweit is thanked for his micropalaeontological advice. Roger Davies provided valuable comments on mid-Cretaceous Arabian stratigraphy, and both he and Malcolm Hart helped with clarifications to the manuscript during its review. Rachel Hopper assisted with figure drafting. Halliburton is thanked for providing the permission to publish.

Financial support. This research has been supported by a national research project (grant no. TUBITAK-111Y138).

Review statement. This paper was edited by Thomas M. Cronin and reviewed by Roger Davies and Malcolm Hart.

\section{References}

Abdallah, H. and Meister, C.: The Cenomanian-Turonian boundary in the Gafsa-Chott area (southern part of central Tunisia): biostratigraphy, palaeoenvironments, Cretaceous Res., 18, 197-236, 1997.

Afghah, M. and Fadaei, H. R.: Biostratigraphy of Cenomanian succession in Zagros area (southwest of Iran), Geosci. J., 19, 257271, 2015.

Afghah, M., Yousefzadeh, A., and Shirdel, S.: Biostratigraphic Revision of Middle Cretaceous Succession in South Zagros Basin (SW of Iran), Journal of Earth Science and Climatic Change, 5, 1000216, https://doi.org/10.4172/2157-7617.1000216, 2014.

Al-Dulaimy, R. T. and Al-Sheikhly, S. S.: Biostratigraphy of the Mishrif Formation from well Amarah-1 Southeastern Iraq, Iraqi Bulletin of Geology and Mining, 9, 1-14, 2013.

Arnaud-Vanneau, A.: Charentia cuvillieri, in: Les grands Foraminiferes du Cretace moyen de la region mediterranenne, edited by: Schroeder, R. and Neumann, M., Geobios, Mem. spec., 7, 17-18, 1985.

Arnaud-Vanneau, A. and Peybernès, B.: Les représentants éocrétacés du genre Nautiloculina Mohler, 1938 (Foraminifera, Fam. Lituolidae?) dans les chaines subalpines septentrionales (Vercors) et les pyrénées Franco-Espagnoles: Revision de Nautiloculina cretacea Peybernès, 1976 et description de Nautiloculina bronnimanni n. sp., Geobios, 11, 67-81, 1978.
Arnaud-Vanneau, A., Boisseau, T., and Darsac, C.: The genus Trocholina Paalzow, 1922 and its main species in the Cretaceous, Revue de Paléobiologie, Special Volume 2, 353-377, 1988.

Assadi, A., Honarmand, J., Moallemi, S. A., and Abdollahie-Fard, I.: Depositional environments and sequence stratigraphy of the Sarvak Formation in an oil field in the Abadan Plain, SW Iran, Facies, 62, https://doi.org/10.1007/s10347-016-0477-5, 2016.

Banner, F. T. and Simmons, M. D.: Calcareous algae and foraminifera as water-depth indicators: an example from the Early Cretaceous carbonates of northeast Arabia, in: Micropalaeontology and Hydrocarbon Exploration in the Middle East, edited by: Simmons, M. D., Chapman and Hall, London, 243-252, 1994.

Banner, F. T., Simmons, M. D., and Whittaker, J. E.: The Mesozoic Chrysalidinidae (Foraminifera, Textulariacea) of the Middle East: the Redmond (Aramco) taxa and their relatives, Bulletin of the British Museum of Natural History (Geology), 47, 101-152, 1991.

Barattolo, F.: Late Cretaceous-Paleogene Dasycladaleans and the $\mathrm{K} / \mathrm{T}$ boundary problem, in: Research advances in calcareous algae and microbial carbonates, edited by: Bucur, I. I. and Filipescu, S., Proceedings of the 4th IFAA Regional Meeting, Cluj Napoca, Romania, 29 August-5 September 2001, 17-40, 2002.

Basson, P. W. and Edgell, H. S.: Calcareous algae from the Jurassic and Cretaceous of Lebanon, Micropaleontology, 17, 411-433, 1971.

Bauer, J., Kuss, J., and Steuber, T.: Sequence architecture and carbonate platform configuration (Late Cenomanian-Santonian), Sinai, Egypt, Sedimentology, 50, 387-414, 2003.

Beer, H.: Mardin-Derik-Mazıdağı çevresindeki fosfatlı tabakaların jeolojisi, Bulletin of Mineral Research and Exploration Institute, 66, 104-120, 1966.

Bucur, I. I., Sudar, M. N., Săsăran, E., Jovanović, D., Pleş, G., and Polavder, S.: Rediscovery of the type locality of the Udoteacean alga Boueina hochstetteri Toula, 1884, in the Lower Cretaceous of Serbia, Carnets Géol., 18, 123-137, 2018.

Calonge, A., Caus, E., Bernaus, J. M., and Aguilar, M.: Praealveolina (Foraminifera) species; a tool to date Cenomanian platform sediments, Micropaleontology, 48, 53-66, 2002.

Caron, M. and Homewood, P.: Evolution of early planktic foraminifers, Mar. Micropaleontol., 7, 453-462, 1983.

Cater, J. M. L. and Gillcrist, J. R.: Karstic reservoirs of the midCretaceous Mardin Group, SE Turkey: tectonic and eustatic controls on their genesis, distribution and preservation, J. Petrol. Geol., 17, 253-278, 1994.

Çelikdemir, M. E., Dulger, S., Gorur, N., Wagner, C., and Uygur, K.: Stratigraphy, sedimentology, and hydrocarbon potential of the Mardin Group, south-east Turkey, in: Generation, Accumulation, and Production of Europe's Hydrocarbons, edited by: Spencer, A. M., Special Publication of the European Association of Petroleum Geologists, 1, 439-454, 1991.

Cherchi, A. and Schroeder, R.: Dicyclina sampoi n. sp., a larger foraminifer from the Cenomanian of Zagros Range (SW Iran), Paläontol. Z., 64, 203-211, 1990.

Consorti, L., Calonge, A., Yazdi-Moghadam, M., and Caus, E.: Involutina hungarica (Sidó, 1952) from the Albian Tethys: Architecture, palaeoenviroment and palaeobiogeography, Cretaceous Res., 51, 266-273, 2014. 
Cros, P., Dercourt, J., Günay, Y., Fourcade, E., Bellier, J. P., Manivit, H., Kozlu, H., and Lauer, J. P.: The Arabian Platform in Southeastern Turkey: an Albian-Cenomanian carbonate ramp collapsed during the Senonian, Bulletin of Turkish Association of Petroleum Geologists, 11, 55-77, 1999.

De Castro, P.: Chrysalidina gradata, in: Les grands Foraminiferes du Cretace moyen de la region mediterranenne, edited by: Schroeder, R. and Neumann, M., Geobios, Mem. spec., 7, $23-$ 27, 1985.

Demirel, I. H. and Guneri, S.: Cretaceous carbonates in the Adiyaman region, SE Turkey: an assessment of burial history and source-rock potential, J. Petrol. Geol., 23, 91-106, 2000.

Demirel, I. H., Yurtsever, T. S., and Guneri, S.: Petroleum systems of the Adiyaman region, southeastern Anatolia, Turkey, Mar. Petrol. Geol., 18, 391-410, 2001.

Dias-Brito, D.: Global stratigraphy, palaeobiogeography and palaeoecology of Albian-Maastrichtian pithonellid calcispheres: impact on Tethys configuration, Cretaceous Res., 21, 315-349, 2000.

Droste, H. and Van Steenwinkel, M.: Stratal geometries and patterns of platform carbonates: the Cretaceous of Oman, in: Seismic Imaging of Carbonate Reservoirs and Systems, edited by: Eberli, G., Masaferro, J. L., and Sarg, J. F. R., American Association of Petroleum Geologists Memoir, Tulsa, USA, 81, 185-206, 2004

El Beialy, S. Y. and Al-Hitmi, H. H.: Micropalaeontology and palynology of the Lower and Middle Cretaceous Thamama and Wasia groups, DK-C well, Dukhan oil field, Western Qatar, Sciences Géologiques Bulletin, 47, 67-95, 1994.

Elliott, G. F.: Algal debris-facies in the Cretaceous of the Middle East, Palaeontology, 1, 254-259, 1958.

Elliott, G. F.: More microproblematica from the Middle East, Micropaleontology, 8, 29-44, 1962.

Elliott, G. F.: Permian to Paleocene calcareous algae Dasycladaceae of the Middle East, Bulletin of the British Museum (Natural History) Geology (Suppl.), 4, 1-111, 1968

El-Naggar, Z. R. and Al-Rifaiy, I. A.: Stratigraphy and microfacies of type Magwa formation of Kuwait, Arabia; part I: Rumaila Limestone Member, AAPG Bull., 56, 1464-1493, 1972.

El-Naggar, Z. R. and Al-Rifaiy, I. A.: Stratigraphy and microfacies of type Magwa Formation of Kuwait, Arabia; Part 2: Mishrif Limestone Member, AAPG Bull., 57, 2263-2279, 1973.

Ettachfini, E. M., Souhel, A., Andreu, B., and Caron, M.: La limite Cénomanien-Turonien dans le Haut Atlas central, Maroc, Geobios, 38, 57-68, 2005.

Farouk, S., Ahmad, F., and Powell, J. H.: Cenomanian-Turonian stable isotope signatures and depositional sequences in northeast Egypt and central Jordan, J. Asian Earth Sci., 134, 207-230, 2017.

Flügel, E.: Halimeda: paleontological record and palaeoenvironmental significance, Coral Reefs, 6, 123-130, 1988.

Gale, A. S., Voigt, S., Sageman, B. B., and Kennedy, W. J.: Eustatic sea-level record for the Cenomanian (Cretaceous) - extension to the Western Interior Basin, USA, Geology, 36, 859-862, 2008.

Georgescu, M. D. and Huber, B. T.: Early evolution of the Cretaceous serial planktic foraminifera (late Albian-Cenomanian), J. Foramin. Res., 39, 335-360, 2009.
Ghanem, H. and Kuss, J.: Stratigraphic control of the AptianEarly Turonian sequences of the Levant Platform, Coastal Range, northwest Syria, GeoArabia, 18, 85-132, 2013.

Ghanem, H., Mouty, M., and Kuss, J.: Biostratigraphy and carbonisotope stratigraphy of the uppermost Aptian to Upper Cenomanian strata of the South Palmyrides, Syria, GeoArabia, 17, 155184, 2012.

Görür, N., Çelikdemir, E., and Dülger, S.: Carbonate platforms developed on passive continental margins: Cretaceous Mardin carbonates in SE Anatolia as an example, Bulletin of the Technical University of Istanbul, 44, 301-324, 1991.

Grélaud, C., Razin, P., and Homewood, P.: Channelized systems in an inner carbonate platform setting: differentiation between incisions and tidal channels (Natih Formation, Late Cretaceous, Oman), Geol. Soc. Lond. Spec. Publ., 329, 163-186, 2010.

Hajikazemi, E., Al-Aasm, I. S., and Coniglio, M.: Subaerial exposure and meteoric diagenesis of the Cenomanian-Turonian Upper Sarvak Formation, southwestern Iran, Geol. Soc. Lond. Spec. Publ., 330, 253-272, 2010.

Hamaoui, M.: On a new subgenus of Hedbergella (Foraminiferaida), Israel J. Earth Sci., 13, 133-142, 1965.

Hamaoui, M.: Nezzazata simplex, in: Les grands Foraminiferes du Cretace moyen de la region mediterranenne, edited by: Schroeder, R. and Neumann, M., Geobios, Mem. spec., 7, 3336, 1985a.

Hamaoui, M.: Biconcava bentori, in: Les grands Foraminiferes du Cretace moyen de la region mediterranenne, edited by: Schroeder, R. and Neumann, M., Geobios, Mem. spec., 7, $37-$ 38, 1985b.

Hamaoui, M.: Biplanata peneropliformis, in: Les grands Foraminiferes du Cretace moyen de la region mediterranenne, edited by: Schroeder, R. and Neumann, M., Geobios, Mem. spec., 7, 39-41, 1985c.

Hamaoui, M. and Saint-Marc, P.: Microfaunes et microfaciès du Cénomanien du Proche-Orient, Bulletin du Centre de Recherches Pau-SNPA, 4, 257-352, 1970.

Hancock, J.: The mid-Cenomanian eustatic low, Acta Geol. Pol., 54, 611-627, 2004.

Haq, B. U.: Cretaceous eustasy revisited, Global Planet. Change, 113, 44-58, 2014.

Hart, M. B.: The Late Cenomanian calcisphere global bioevent, Proc. Ussher, 7, 413-417, 1991.

Hart, M. B.: The evolution and biodiversity of Cretaceous planktonic foraminifera, Geobios, 32, 247-255, 1999.

Hart, M. B. and Bailey, H. W.: The distribution of planktonic Foraminiferida in the mid-Cretaceous of NW Europe, in: Aspekte der Kreide Europas, edited by: Wiedmann, J., IUGS, Stuttgart, Series A, 6, 527-542, 1979.

Hart, M. B. and Leary, P. N.: Periodic bioevents in the evolution of the planktonic foraminifera, in: Extinction Events in Earth History, Springer, Berlin, Heidelberg, 325-331, 1990.

Henson, F. R. S.: Foraminifera of the genus Trocholina in the Middle East, Ann. Mag. Nat. Hist., 14, 445-459, 1947.

Henson, F. R. S.: Recent publications on larger imperforate foraminifera of the Middle East, J. Nat. Hist., 2, 173-177, 1949.

Hohenegger, J.: Large Foraminifera: Greenhouse Constructions and Gardeners in the Oceanic Microcosm, Kagoshima University Museum Bulletin, 5, 1-81, 2011. 
Hollis, C.: Diagenetic controls on reservoir properties of carbonate successions within the Albian - Turonian of the Arabian Plate, Petrol. Geosci., 17, 223-241, 2011.

Homewood, P., Razin, P., Grélaud, C., Droste, H., Vahrenkamp, V., Mettraux, M., and Mattner, J.: Outcrop sedimentology of the Natih Formation, northern Oman: A field guide to selected outcrops in the Adam Foothills and Al Jabal al Akhdar areas, GeoArabia, 13, 39-120, 2008.

Hoşgör, İ. and Yılmaz, İ. Ö.: Paleogeographic northeastern limits of Aphrodina dutrugei (Cocquand, 1862) (Heterodonta, Bivalvia) from the Cenomanian of the Arabian Platform, Riv. Ital. Paleontol. S., 125, 421-431, 2019.

Hottinger, L.: Illustrated glossary of terms used in foraminiferal research, Carnets de Geologie, Memoir 2006/02, https://doi.org/10.4267/2042/5832, 2006.

Hughes, G. W.: Late Permian to Late Jurassic "microproblematica" of Saudi Arabia: Possible palaeobiological assignments and roles in the palaeoenviromental reconstructions, GeoArabia, 18, 5792, 2013.

Jaff, R. B. N., Wilkinson, I. P., Lee, S., Zalasiewicz, J., Lawa, F., and Williams, M.: Biostratigraphy and palaeoceanography of the early Turonian-early Maastrichtian planktonic foraminifera of NE Iraq, J. Micropalaeontol., 34, 105-138, https://doi.org/10.1144/jmpaleo2014-020, 2015.

Kalanat, B. and Vaziri-Moghaddam, H.: Ecological changes and depositional sequences during Cenomanian/Turonian platform evolution in the Zagros Basin, SW Iran; an interplay between tectonics and aquifer-eustasy, Sediment. Geol., 390, 31-44, 2019.

Kuss, J.: Upper Cretaceous (Albian-Turonian) calcareous algae from Egypt and Jordan - systematics, stratigraphy, and paleogeography, Jahrbuch der Geologischen Bundesanstalt Wien, 50, 295-317, 1994.

Kuss, J. and Conrad, M. A.: Calcareous algae from Cretaceous carbonates of Egypt, Sinai, and southern Jordan, J. Paleontol., 65, 869-882, 1991.

Kuss, J. and Schlagintweit, F.: Facies and stratigraphy of early to middle cretaceous (Late Aptian-Early Cenomanian) strata from the northern rim of the African Craton (Gebel Maghara-Sinai, Egypt), Facies, 19, 77-95, 1988.

Kuss, J. and Senowbari-Daryan, B.: Anomuran coprolites from Cretaceous shallow water limestones of NE Africa, Cretaceous Res., 13, 147-156, 1992.

Leckie, R. M.: Foraminifera of the Cenomanian-Turonian Boundary Interval, Greenhorn Formation, Rock Canyon Anticline, Pueblo, Colorado, in: Fine-grained deposits and biofacies of the Cretaceous Western Interior Seaway: Evidence of cyclic sedimentary processes, edited by: Pratt, L. M., Kauffman, E. G., and Zelt, F. B., SEPM Field Trip Guidebook No. 4, SEPM, Tulsa, USA, 139-149, 1985.

Lézin, C., Andreu, B., Ettachfini, E. M., Wallez, M. J., Lebedel, V., and Meister, C.: The upper Cenomanian-lower Turonian of the Preafrican Trough, Morocco, Sediment. Geol., 245, 1-16, 2012.

Lipson-Benitah, S., Almogi-Labin, A., and Sass, E.: Cenomanian biostratigraphy and palaeoenvironments in the northwest Carmel region, northern Israel, Cretaceous Res., 18, 469-491, 1997.

Mahdi, T. A. and Aqrawi, A. A. M.: Sequence stratigraphic analysis of the mid-Cretaceous Mishrif Formation, southern Mesopotamian Basin, Iraq, J. Petrol. Geol., 37, 287-312, 2014.
Moullade, M. and Peybernés, B.: Etude microbiostratigraphique de l'Albien du Massif de Montgri (Prov. Gerona, Espagne), description de Hensonina nov. gen. (Générotype: Trocholina lenticularis Henson, 1947) (Foraminiferida, Fam. Involutinidae), Arch. Sci., 26, 173-181, 1974.

Mouty, M., Al Maleh, A. K., and Abou Laban, H.: Le Crétacé moyen de la chaîne des Palmyrides (Syrie centrale), Geodiversitas, 25, 429-443, 2003.

MTA: Diyarbakır-N 44 Paftası, no: 168., 1/100000 €olçekli Türkiye Jeoloji Haritası, 42 pp., 2011.

Mülayim, O., Mancini, E., Cemen, I., and Yılmaz, İ. Ö.: Upper Cenomanian-Lower Campanian Derdere and Karababa formations in the Çemberlitaş oil field, southeastern Turkey: their microfacies analyses, depositional environments, and sequence stratigraphy, Turk. J. Earth Sci., 25, 46-63, 2016.

Mülayim, O., Yılmaz, İ. Ö., and Ferré, B.: Roveacrinid microfacial assemblages (Roveacrinida, Crinoidea) from the Lower-Middle Cenomanian of the Adiyaman area (SE Turkey), Arab. J. Geosci., 11, 545, https://doi.org/10.1007/s12517-018-3901-z, 2018.

Mülayim, O., Yılmaz, İ. Ö., Sarı, B., Taslı, K., and Wagreich, M.: Cenomanian-Turonian drowning of the Arabian Carbonate Platform, the İnişdere section, Adıyaman, SE Turkey, in: Cretaceous Climate Events and Short-Term Sea-Level Changes, edited by: Wagreich, M., Hart, M. B., Sames, B., and Yilmaz, İ. Ö., Geological Society, London, Special Publications, London, 498, https://doi.org/10.1144/SP498-2018-130, 2019a.

Mülayim, O., Yılmaz, İ. Ö., Sarı, B., and Tasl1, K.: Carbon-isotope stratigraphy of the Cenomanian-Turonian carbonate succession of the Türkoğlu section (SE Turkey): implications for the timing of Late Cretaceous sea-level rise and anoxic event, IESCA 2019, Conference Abstracts, Dokuz Eylül University, İzmir, Turkey, 2019b.

Mülayim, O., Yılmaz, İ. Ö., Özer, S., Sarı, B., and Taslı, K.: A Cenomanian-Santonian rudist-bearing carbonate platform on the northern Arabian Plate, Turkey: facies and sequence stratigraphy, Cretaceous Res., 110, https://doi.org/10.1016/j.cretres.2020.104414, 2020.

Navidtalab, A., Heimhofer, U., Huck, S., Omidvar, M., RahimpourBonab, H., Aharipour, R., and Shakeri, A.: Biochemostratigraphy of an upper Albian-Turonian succession from the southeastern Neo-Tethys margin, SW Iran, Palaeogeogr. Palaeocl., 533, 109255, https://doi.org/10.1016/j.palaeo.2019.109255, 2019.

Norris, R. D. and Wilson, P. A: Low-latitude sea-surface temperatures for the mid-Cretaceous and the evolution of planktic foraminifera, Geology, 26, 823-826, 1998.

Okay, A. I. and Tüysüz, O.: Tethyan sutures of northern Turkey, Geol. Soc. Lond. Spec. Publ., 156, 475-515, 1999.

Okay, A. I., Satir, M., and Siebel, W.: Pre-Alpide Palaeozoic and Mesozoic orogenic events in the Eastern Mediterranean region, Geol. Soc. Lond. Mem., 32, 389-405, 2006.

Omidvar, M., Mehrabi, H., Sajjadi, F., Bahramizadeh-Sajjadi, H., Rahimpour-Bonab, H., and Ashrafzadeh, A.: Revision of the foraminiferal biozonation scheme in Upper Cretaceous carbonates of the Dezful Embayment, Zagros, Iran: integrated palaeontological, sedimentological and geochemical investigation, Revue de micropaléontologie, 57, 97-116, 2014.

Özkan, R. and Altıner, D.: The Cretaceous Mardin Group carbonates in southeast Turkey: lithostratigraphy, foraminiferal biostratigraphy, microfacies and sequence 
stratigraphic evolution, Cretaceous Res., 98, 153-178, https://doi.org/10.1016/j.cretres.2018.09.021, 2019.

Parnian, B., Ahmadi, V., Saroii, H., and Bahrami, M.: Biostratigraphy and palaeodepositional model of the Sarvak Formation in the Fars Zone, Zagros, Iran, Journal of Himalayan Earth Sciences, 52, 197-216, 2019.

Petrizzo, M. R.: Palaeoceanographic and palaeoclimatic inferences from Late Cretaceous planktonic foraminiferal assemblages from the Exmouth Plateau (ODP Sites 762 and 763, eastern Indian Ocean), Mar. Micropaleontol., 45, 117-150, 2002.

Pia, J.: Description of the algae, in: Fossil algae from the Uppermost Cretaceous beds of the Ninyur Group of the Trichinopoly District, S. India, edited by: Rao, L. R. and Pia, J., Palaeontology India (N.S.), 21, 1-49, 1936.

Piuz, A. and Meister, C.: Cenomanian rotaliids (Foraminiferida) from Oman and Morocco, Swiss Journal of Palaeontology, 132, 81-97, 2013.

Piuz, A., Meister, C., and Vicedo, V.: New Alveolinoidea (Foraminifera) from the Cenomanian of Oman, Cretaceous Res., 50, 344-360, 2014.

Poignant, A. F.: Les Algues rouges cenomaniennes, Géologie Méditerranéenne, 5, 69-171, 1978.

Premoli Silva, I. and Verga, D.: Practical Manual of Cretaceous Planktonic Foraminifera, in: International School on Planktonic Foraminifera, $3^{\circ}$ Course: Cretaceous, edited by: Verga, D. and Rettori, R., Universities of Perugia and Milan, Tipografia Pontefelcino, Perugia, Italy, 2004.

Rahimpour-Bonab, H., Mehrabi, H., Enayati-Bidgoli, A. H., and Omidvar, M.: Coupled imprints of tropical climate and recurring emergence on reservoir evolution of a mid Cretaceous carbonate ramp, Zagros Basin, southwest Iran, Cretaceous Res., 37, 15-34, 2012.

Ray, D., van Buchem, F. S., Baines, G., Davies, A., Gréselle, B., Simmons, M. D., and Robson, C.: The magnitude and cause of short-term eustatic Cretaceous sea-level change: A synthesis, Earth-Sci. Rev., 102901, https://doi.org/10.1016/j.earscirev.2019.102901, 2019.

Razin, P., Taati, F., and Van Buchem, F. S. P.: Sequence stratigraphy of Cenomanian-Turonian carbonate platform margins (Sarvak Formation) in the High Zagros, SW Iran: an outcrop reference model for the Arabian Plate, in: Mesozoic and Cenozoic Carbonate Systems of the Mediterranean and the Middle East: Stratigraphic and Diagenetic Reference Models, edited by: van Buchem, F. S. P., Gerdes, K. D., and Esteban, M., Geological Society, London, Special Publications, 329, 187-218, 2010.

Reichel, M.: Sur une Alvéoline cénomanienne du Bassin du Beausset, Eclogae Geol. Helv., 26, 269-280, 1933.

Reichel, M.: Etude sur les Alvéolines, Mém. Soc. Paléont. Suisse, 57, 1-93, 1936.

Rigaud, S., Blau, J., Martini, R., and Rettori, R.: Taxonomy and phylogeny of the Trocholinidae (Involutinina), J. Foramin. Res., 43, 317-339, 2013.

Robertson, A., Boulton, S. J., Taslı, K., Yıldırım, N., İnan, N., Yildı, A., and Parlak, O.: Late Cretaceous-Miocene sedimentary development of the Arabian continental margin in SE Turkey (Adiyaman region): Implications for regional palaeogeography and the closure history of southern Neotethys, J. Asian Earth Sci., $115,571-616,2016$.
Rosales, I. and Schlagintweit, F.: The uppermost Albianlower Cenomanian Bielba Formation of the type-area (Cantabria, northern Spain): facies, biostratigraphy, and benthic Foraminifera, Facies, 61, https://doi.org/10.1007/s10347-0150441-9, 2015.

Saber, S. G., Salama, Y. F., Scott, R. W., Abdel-Gawad, G. I., and Aly, M. F.: Cenomanian-Turonian rudist assemblages and sequence stratigraphy on the North Sinai carbonate shelf, Egypt, GeoArabia, 14, 113-134, 2009.

Saint-Marc, P.: Etude stratigraphique et micropaléontologique de l'Albien, du Cénomanien et du Turonien du Liban, Notes Mémoires Moyen-Orient, 13, 1-342, 1974.

Sames, B., Wagreich, M., Wendler, J. E., Haq, B. U., Conrad, C. P., Melinte-Dobrinescu, M. C., Hu, X., Wendler, I., Wolfgring, E., Yılmaz, I. Ö., and Zorina, S. O.: Review: Short-term sea-level changes in a greenhouse world - A view from the Cretaceous, Palaeogeogr. Palaeocl., 441, 393-411, 2016.

Sampo, M.: Microfacies and Microfossils of the Zagros Area, south-western Iran, E.J. Brill, Leiden, The Netherlands, 102 pp., 1969.

Sarı, B., Taslı, K., and Özer, S.: Benthonic foraminiferal biostratigraphy of the Upper Cretaceous (middle Cenomanian-Coniacian) sequences of the Bey Daglaricarbonate platform, western Taurides, Turkey, Turkish J. Earth Sci., 18, 393-425, 2009.

Sartorio, D. and Venturini, S.: Southern Tethys Biofacies, Agip SPA, Donato Milanese, 235 pp., 1988.

Schlagintweit, F.: Further record of calcareous algae (dasycladaceae, udoteaceae, solenoporaceae) from the Upper Cretaceous of the Northern Calcareous Alps (Gosau Formation, Branderfleck Formation), Revue de Paléobiologie, 11, 1-12, 1992.

Schlagintweit, F.: Taxonomic review of some Late Jurassic - Early Cretaceous benthic foraminifera established by Gollestaneh (1965) from the Zagros fold and thrust belt of Iran, Acta Palaenologica Romaniae, 9, 27-31, 2014.

Schlagintweit, F. and Piller, W.: Involutina hungarica (Sido) from allochthonous Urgonian limestones of the Northern Calcareous Alps and remarks on the genus Hensonina Moullade and Peybernès, 1974, Beitr. Paläont. Österr., 16, 145-153, 1990.

Schlagintweit, F. and Wilmsen, M.: Calcareous algae (dasycladales, udoteaceae) from the Cenomanian Altamira Formation of northern Cantabria, Spain, Acta Palaeontologica Romaniae, 10, 1524, 2014

Schlagintweit, F. and Yazdi-Moghadam, M.: Orbitolinopsis cenomaniensis n. sp., a new larger benthic foraminifera (Orbitolinidae) from the middle-late Cenomanian of the Sarvak Formation (SW Iran, Zagros Zone): a regional marker taxon for the Persian Gulf area and Oman, Revue de micropaléontologie, 67, 100413, https://doi.org/10.1016/j.revmic.2020.100413, 2020.

Schlagintweit, F., Rigaud, S., and Wilmsen, M.: Insights from exceptionally preserved Cenomanian trocholinids (benthic foraminifera) of northern Cantabria, Spain, Facies, 61, https://doi.org/10.1007/s10347-014-0416-2, 2015.

Schlagintweit, F., Rashidi, K., and Babadipour, M.: Orbitolinid foraminifera from the Late Maastrichtian of the Tarbur Formation (Zagros Zone, SW Iran), Acta Palaeontologica Romaniae, 12, 29-46, 2016.

Schroeder, R. and Neumann, M. (Eds.): Les grands Foraminiferes du Cretace moyen de la region mediterranenne, Geobios, Special Publication, Lyon. Mem. spec., 7, 160 pp., 1985. 
Schulze, F., Lewy, Z., Kuss, J., and Gharaibeh, A.: CenomanianTuronian carbonate platform deposits in west central Jordan, Int. J. Earth Sci., 92, 641-660, 2003.

Schulze, F., Marzouk, A. M., Bassiouni, M. A., and Kuss, J.: The late Albian-Turonian carbonate platform succession of westcentral Jordan: stratigraphy and crises, Cretaceous Res., 25, 709737, 2004.

Schulze, F., Kuss, J., and Marzouk, A.: Platform configuration, microfacies and cyclicities of the upper Albian to Turonian of westcentral Jordan, Facies, 50, 505-527, 2005.

Şengör, A. C. and Y1lmaz, Y.: Tethyan evolution of Turkey: a plate tectonic approach, Tectonophysics, 75, 181-241, 1981.

Shahin, A. and Elbaz, S.: Foraminiferal biostratigraphy, paleoenvironment and paleobiogeography of Cenomanian-Lower Turonian shallow marine carbonate platform in west central Sinai, Egypt, Micropaleontology, 59, 249-283, 2013.

Sharland, P. R., Archer, R., Casey, D. M., Davies, R. B., Hall, S. H., Heward, A. P., Horbury, A. D., and Simmons, M. D.: Arabian Plate Sequence Stratigraphy, GeoArabia Special Publication, 2, 371 pp., 2001.

Sharp, I., Gillesoie, P., Morsalnezhad, D., Taberner, C., Karpuz, R., Verges, J., Horbury, A., Pickard, N., Garland, J., and Hunt, D.: Stratigraphic architecture and fracture controlled dolomitization of the Cretaceous Khami and Bangestan groups: an outcrop case study, Zagros Mountains, Iran, in: Mesozoic and Cenozoic Carbonate Systems of the Mediterranean and the Middle East: Stratigraphic and Diagenetic Reference Models, edited by: van Buchem, F., Gerdes, K., and Esteban, M., Geological Society, London, Special Publications, 329, 343-396, 2010.

Shirazi, M. P. N.: Calcareous algae from the Cretaceous of Zagros Mountains (SW Iran), World Appl. Sci. J., 4, 803-807, 2008.

Shirazi, M. P. N., Bahrami, M., Rezaee, B., and Gharamani, S.: Microbiostratigraphy of Kazhdumi formation in the Northwestern Shiraz (Southwest Iran) on the basis of foraminifera and calcareous algae, Acta Geol. Sin.-Engl., 85, 777-783, 2011.

Simmons, M. D. and Hart, M. B.: The biostratigraphy and microfacies of the Early to mid-Cretaceous carbonates of Wadi Mi'aidin, central Oman Mountains, in: Micropalaeontology of Carbonate Environments, John Wiley \& Sons, Chichester, UK, 176-207, 1987.

Simmons, M. D., Miller, K. G., Ray, D. C., Davies, A., van Buchem, F. S. P., and Gréselle, B.: Phanerozoic eustasy, in: A Geological Time Scale 2020, Elsevier, Amsterdam, 357-400, 2020.

Smith, A. B., Simmons, M. D., and Racey, A.: Cenomanian echinoids, larger foraminifera and calcareous algae from the Natih Formation, central Oman Mountains, Cretaceous Res., 11, 2969, 1990.

Solak, C., Taslı, K., Özer, S., and Koç, H.: The Madenli (Central Taurides) Upper Cretaceous platform carbonate succession: Benthic foraminiferal biostratigraphy and platform evolution, Geobios, 52, 67-83, 2019.

Stampfli, G. M. and Borel, G. D.: A plate tectonic model for the $\mathrm{Pa}$ leozoic and Mesozoic constrained by dynamic plate boundaries and restored synthetic oceanic isochrons, Earth Planet. Sc. Lett., 196, 17-33, 2002.

Toulabi, L. and Roozbahani, P. R.: Stratigraphy and foraminiferal biozonation of Upper Cretaceous deposits in south-west of Iran (Khorramabad-Kuhdasht), Buletin Teknologi Tanaman, 12, 9295, 2015. van Buchem, F. S., Razin, P., Homewood, P. W., Philip, J. M., Eberli, G. P., Platel, J. P., Roger, J., Eschard, R., Desaubliaux, G. M., Boisseau, T., and Leduc, J. P.: High resolution sequence stratigraphy of the Natih Formation (Cenomanian/Turonian) in northern Oman: distribution of source rocks and reservoir facies, GeoArabia, 1, 65-91, 1996.

van Buchem, F. S. P., Simmons, M. D., Droste, H. J., and Davies, R. B.: Late Aptian to Turonian stratigraphy of the eastern Arabian Plate-depositional sequences and lithostratigraphic nomenclature, Petrol. Geosci., 17, 211-222, 2011.

Velić, I.: Stratigraphy and palaeobiogeography of Mesozoic benthic foraminifera of the Karst Dinarides (SE Europe), Geol. Croat., 60, 1-60, 2007.

Vérard, C., Hochard, C., Baumgartner, P. O., Stampfli, G. M., and Liu, M.: Geodynamic evolution of the Earth over the Phanerozoic: Plate tectonic activity and palaeoclimatic indicators, J. Palaeogeogr., 4, 167-188, 2015.

Vicedo, V.: Morfoestructura de los géneros cretácicos de los Rhapydioninidae (Foraminifera), Universitat Autònoma de Barcelona, 2009.

Vicedo, V. and Piuz, A.: Evolutionary trends and biostratigraphical application of new Cenomanian alveolinoids (Foraminifera) from the Natih Formation of Oman, J. Syst. Palaeontol., 15, 821850, 2017.

Vicedo, V. and Serra-Kiel, J.: Decastroia razini n. gen. n. sp. - A new alveolinacean (foraminifera) from the Cenomanian of Socotra Island (Yemen), GeoArabia, 16, 17-26, 2011.

Vicedo, V., Calonge, A., and Caus, E.: Cenomanian rhapydioninids (Foraminiferida): architecture of the shell and stratigraphy, J. Foramin. Res., 41, 41-52, 2011.

Vincent, B., van Buchem, F. S., Bulot, L. G., Jalali, M., Swennen, R., Hosseini, A. S., and Baghbani, D.: Depositional sequences, diagenesis and structural control of the Albian to Turonian carbonate platform systems in coastal Fars (SW Iran), Mar. Petrol. Geol., 63, 46-67, 2015.

Wendler, J. E., Wendler, I., Huber, B., and Macleod, K. G.: What are calcispheres? Pristine specimens from the Tanzania drilling project provide unprecedented insight into an enigmatic Cretaceous Microfossil Group, Geological Society of America, Abstracts with Program, Boulder, USA, Vol. 42, p. 131, 2010.

Wilmsen, M. and Nagm, E.: Sequence stratigraphy of the lower Upper Cretaceous (Upper Cenomanian-Turonian) of the Eastern Desert, Egypt, Newsl. Stratigr., 46, 23-46, 2013.

Wohlwend, S., Hart, M., and Weissert, H.: Chemostratigraphy of the Upper Albian to mid-Turonian Natih Formation (Oman) how authigenic carbonate changes a global pattern, Depositional Record, 2, 97-117, 2016.

Yetim, S. M. and Altıner, D.: Evaluation of Reservoir Quality of Mardin Group Carbonates within the Sequence Stratigraphy Framework in Adiyaman and Diyarbakir Regions, SE Turkey, Geophys. Res. Abstr., EGU2019-982, EGU General Assembly 2019, Vienna, Austria, 2019.

Yılmaz, İ. Ö.: Taxonomic and paleogeographic approaches to the dasyclad algae in the Upper Jurassic (Kimmeridgian) and Upper Cretaceous (Cenomanian) peritidal carbonates of the Fele (Yass1bel) area (Western Taurides, Turkey), Turkish J. Earth Sci., 8, 81-101, 1999. 